\title{
The politics behind the veil ${ }^{1}$
}

\author{
Ozan Aksoy* \\ University College London \\ ozan.aksoy@ucl.ac.uk
}

\author{
Diego Gambetta \\ Collegio Carlo Alberto, Turin \\ diego.gambetta@carloalberto.org
}

Version: 27 April 2020

\begin{abstract}
:
Using a natural experiment, we find that in provinces where Turkey's Islamic Justice and Development Party (AKP) just won the election in 2004, women, including those who are weakly- or non-religious, now veil far more than in provinces in which AKP just lost, the more so the poorer they are. This effect, as we predict, does not occur for praying regularly which is a more costly and harder to observe practice. We argue that veiling is higher in AKP provinces not only because of a generic aim to conform to the stricter mores fostered by the victorious party. We find that those who veil, particularly those in AKP provinces who are not pious, are more politically active than those who do not veil. This may be an indication that veiling could partly be a strategic response to policies, which favour those who are or appear pious. Our study suggests that observable religious practices may have their independent dynamics driven by the pursuit of instrumental goals. Our results also suggest that parties with a religious ideology have an advantage over their secular counterparts in solving the clientelistic information problem, for they can rely on religious symbols for screening and signalling.
\end{abstract}

Word count: < 11,000 (including everything but tables, figures and abstract)

Keywords: Islamic veiling, clientelism, signal, reputation, natural experiment

\footnotetext{
${ }^{1}$ We thank Timur Kuran, Werner Raub, Aron Szekely, David Laitin, David Voas, the editor and the three anonymous reviewers of ESR for their comments on earlier drafts, the participants of the Fifth International Meeting on Experimental and Behavioral Social Sciences particularly Johanna Greke, Macartan Humphreys, Krzysztof Krakowski, Cristine Legare, and Wojtek Przepiorka, and the participants of the UCL Department of Quantitative Social Science Seminar Series for insightful suggestions. *Corresponding author.
} 
Most religions possess distinctive appurtenances donned by their members - skullcaps, veils, singular hairdos, coloured robes, symbolic jewellery, beards and many more. Where the use of religious insignia is imposed by authorities - such as women's veiling in Saudi Arabia - their universal diffusion testifies only of a given religion's dominance, but it reveals nothing of the frequency of believers since unbelievers too are forced to adopt them. Conversely, where these appurtenances are banned - such as Muslim men's beards in Tajikistan - their universal absence does not exclude the concealed presence of true believers. Imposition in these matters stunts information (Aksoy and Gambetta 2016: 804).

Where people are free to decide on their "plumage", by contrast, the display of these appurtenances can afford reliable information on the presence of religious beliefs: information is perfect if all and only true believers adopt them (and by implication all and only unbelievers do not). This equilibrium, in which people's outward appearances perfectly match their inner religious beliefs, is sustained by two states of affairs in neither of which there is any tangible benefit to be deemed either religious or unreligious: a universalistic one in which rewards are apportioned regardless of religiosity; and a sectarian one in which religious and secular flocks receive comparable rewards by their respective communities. In neither case one has any reason to appear as religiously other than one truly is.

Seldom, however, are these states of affairs perfectly realised. In reality, we conjecture, social and political forces conspire to introduce a mismatch between outfit and beliefs. Particularly, we investigate whether a shift in tangible rewards in favour of religious people, brought about by political change, can foster such a mismatch, and turns overt religious appurtenances into covert insignia of political allegiance/loyalty. We do so for one form of religious display, Muslim women's veiling, and study what happens to veiling when the incentives to piety are increased. 
We use a Regression Discontinuity Design (RDD, Morgan and Winship 2007, Gangl 2010), exploiting marginal electoral wins of Turkey's Islamic Justice and Development Party ( $A K$ Parti). We then validate the RDD analysis with multilevel regressions and a difference-indifference analysis.

Our study offers three contributions. First, contrary to a traditional sociological approach that considers religious practices a mere reflection of religiosity (see e.g. Fleischmann and Phalet 2015, Brüning and Fleischmann 2012, Voas 2007), we add to the studies in the sociology of religion that argue that observable religious practices have their independent dynamics driven by the pursuit of mundane goals - e.g. signalling respectability and finding partners (Patel 2012), gravitating to 'respectable' denominations with an aim to join the elite (Davidson, Pyle, and Reyes 1995), or even increasing one's children's chances to be accepted into church-run schools (Francis and Hutchings 2013). We uncover how macro political shifts affect religious micro behaviour among those whose religious beliefs are feeble or absent: if piety pays off, women can choose to adopt one of its outward manifestations, veiling.

Next, we contribute to the literature on clientelism and political machines (Merton 1968). The classic problem of clientelistic political parties concerns information: to whom to dispense patronage and whom to exclude (Stokes et al. 2013, Hicken 2011). In order to maximise electoral support, political machines must screen voters and target only those responsive to inducements and exclude others. Simultaneously, voters have an interest to signal to the party machine that they are worthy of patronage. Since some voters could mimic support, the genuine clients are compelled to search for credible signals to distinguish themselves from the mimics. Literature has mostly focused on the screening mechanisms (Hicken 2011). We take into consideration both signalling and screening. We study the link between voters' signalling of allegiance and party's 
payoffs from patronage; and by arguing that religious behaviours and appurtenances have particular properties that make them more efficient for signalling and screening political allegiance than comparable signals associated to secular parties.

Third, we contribute to the understanding of political Islam's success in expanding its power in Turkey. We document a strong positive effect of local Islamic governance on the prevalence of veiling. We explain this effect by the success of the AK Parti and its grassroots organizations in providing social assistance and welfare to create selective incentives for the "pious and the poor" (Meyersson 2014, Aksoy and Billari 2018). In this sense, the case of political Islam epitomised by the rise of the AK Parti in Turkey shares many parallels with successful political movements elsewhere, whether religious or ideological: a strong emphasis on mutual aid, charitable giving, and the provision of basic local services in recruiting and retaining followers (Berman 2011, Blaydes 2014). We find that veiled women, particularly those who are not pious, are more politically engaged than the unveiled ones - evidence that an upward shift in veiling can be politically rather than religiously driven.

\section{Theory and hypotheses}

Veiling - it is commonly assumed - reflects a woman's piety and modesty, hence should track religiosity. As various sociological theories predict (see Ruiter and Van Tubergen 2009), modernization brings about a decline in religiosity, which should be accompanied by a decline in veiling. There is evidence supporting this prediction. However, it seems to apply only to women who are weakly- or un-religious. Among highly religious women the opposite seems to occur, and for them modernizing forces - education, occupation and higher income, urban living, and contacts with non-Muslims - are associated with an increase in both the frequency and strictness 
of veiling (Aksoy and Gambetta 2016). A plausible interpretation is that modernization raises women's opportunities to abandon piety, or even just the suspicion that they may be doing so, hence the need to reassure the community of their modesty: veiling would represent a strategic response to the threat modernisation poses to truly religious women's reputation, a way for them to signal their resilient piety (Patel 2012, Carvalho 2013).

The evidence, overall, shows that veiling responds to social circumstances and is not dictated merely by religious rulings or concerns; but it also shows that veiling remains consistent with religiosity or the lack of it. Here we take a step further and investigate whether women's veiling also has a strategic component independent of religiosity: are there conditions under which even weakly- or un-religious women decide to veil?

We conceive of two types of motives that could induce feebly religious women to veil voluntarily. One is to conform to prevailing mores and the other is to persuade specific observers of their piety or some other trait closely related to piety. The former is created by social pressures that produce a conformism effect. If veiling among the faithful spread it becomes progressively harder not to conform even for women whose religiosity is weak or absent, and even in the absence of compulsory measures - for as simple a reason as not wanting to stick out and raise questions about their respectability or receive social approval from the community. Veiling in this case does not aim at a specific audience, but rather to avoid negative consequences from the community. Donning the veil despite being weakly religious due to community pressure is one instance of "preference falsification", a phenomenon first studied by Timur Kuran (1995, p.8-9).

The second type of motives is signalling. Signalling motives are supported by the belief that piety matters crucially for those who can choose whether to bestow benefits on a woman, her family, or her wider ingroup and community. In this case, veiling is adopted strategically, as a 
signal of piety aimed at particular receivers, such as potential partners (Patel 2012), probable employers or religious and political organisations which may offer welfare assistance and jobs to a women or members of her family or her wider ingroup and community (Aksoy 2017). Unlike the conformism effect, the signalling effect is not frequency-dependent - it does not necessarily become stronger as the frequency of veiled women increases.

The two motives, community pressure and signalling, can coexist and reinforce each other. We believe the signalling motives are rather strong in our context. To explain why this is so, we need to shift our attention to politics. "Under clientelism, parties distribute benefits to individuals and attempt to hold them accountable for their votes. (...) Parties need to know (...) who will vote for them come hell or high water, who will not vote for them come hell or high water, and who is on the fence" (Stokes et al. 2013, p.19). Past research has shown that parties rely on several mechanisms for screening. For example, repeated interactions with the client and social networks of the party and local brokers provide valuable information on the reliability of the client (Hicken 2011). Religious parties may have an advantage over secular ones as they can exploit religious networks (churches, mosques, associations) and brokers (priests, imams) for screening. Indeed, Kalyvas (1996) argues that the Catholic Church's extensive network of active clergy was a mechanism that contributed to the success of Christian Democracy in Europe.

The clientelistic information problem also has a client side. Voters eager to benefit from patronage want to signal their loyalty to the victor (Corstange 2016). Those with a history of supporting the winning party and connected with the party apparatus should have no difficulties to be identified as genuine. Yet, voters who want to benefit from patronage but whose allegiance is opaque need to invest resources to make their support manifest and credible. The incentive to do so is greater if the party's patronage is expected to strongly favour its supporters, actual or 
potential, at the expense of the rest. At a minimum, these voters express their newly acquired political loyalties by publicly displaying the victors' insignia, e.g., brown shirts for the Nazis, black shirts for the Fascists, green shirts for the Italian Northern League, red bonnets made fashionable by Hugo Chavez, hammer and sickle pins, or fascist Roman salutes.

Not displaying the insignia of the victor party can prove costly: it sends the message that one is indifferent or hostile to the victor despite the benefits of jumping on the wagon - whether because the expected benefits are too low to bother or the conflicting preferences too strong. It is a credible signal of opposition. The reverse, however, is not as convincing a signal of support: there is no guarantee that an individual who displays the victor's insignia voted for the victor or will do so in the future. Donning a red bonnet or making a Roman salute are near-costless acts, which opportunistic mimics too can afford. Before distributing resources, a secular party requires more reliable signals of voters' allegiance.

Parties with a religious connotation and their clients have a distinctive advantage in this regard. In addition to the methods available to secular parties, religious parties and their voters can rely on a set of well-established religious signals. This set, which is greater than the set at the disposal of secular parties and their voters, has two further advantages.

First, truly religious people incur no extra cost to signal their preferences, as these transpire from what they naturally do. If voters' religiosity is a strong indication that they support the party that best takes care of their interests and beliefs, then these behaviours also obliquely signal political support. Many religious practices which have intrinsically high costs - think of long-term fasting, celibacy, self-flagellation, bodily modifications, generously giving to charity, attending regularly religious functions and more - can work in this way for only true believers are prepared to afford them. If having religious beliefs is associated to the support of a religious political 
party, then performing any of the above acts would credibly signal not just one's true religious beliefs but indirectly one's political preferences too. However, political parties with a religious connotation cannot pick their supporters on these very costly religious practices. Parties seek to obtain popular majority and hence cannot afford to appeal only to the extreme fringes of religiosity.

Secondly, although voters who are feebly or unreligious have to pay a cost to pretend religiosity, the set of signals at the religious parties' disposal is likely to contain also some signal that is costly enough to be persuasive but not exorbitantly so. Veiling, we argue, is just such a signal.

According to signalling theory, if a receiver fears to be deceived by a signaller, that is by signallers who display evidence of having a certain quality when this is untrue, honest signallers need to undertake an action the cost of which is such as to separate them from dishonest signallers, the mimics, for it is unaffordable by them. To be convincing this action must be affordable only or nearly only by those who are signalling honestly, but not by mimics (Spence 1974, Zahavi and Zahavi 1998, Gambetta 2009).

Veiling does not have high intrinsic costs, it can be bought inexpensively and wearing it does not impose forbidding costs for weak or unbelievers either: it is rather a nuisance for the nonreligious, a constraint on vanity and freedom of bodily movement. ${ }^{2}$ This is not to dismiss that veiling could be highly costly depending on the context. In Europe for example, veiling attracts discrimination (Aksoy and Gambetta 2016). In secular Turkey too, before the AK Parti reign began, veiled women were under constant state pressure not to veil (Somer 2017). In such high

\footnotetext{
${ }^{2}$ A potentially serious cost of veiling is vitamin-D deficiency due to lower exposure to sunrays. This effect is yet to be properly established (Baroncelli et al. 2008).
} 
cost environments, veiling clearly signals religiosity, and could be used as a reliable signal of support by Islamic political parties. But why even in relatively low-cost environments, such as in the late AK Parti reign, veiling could be an effective signal of political allegiance? It is not difficult to grasp why clients who want to signal allegiance to the religious party would prefer veiling to more costly (or less visible) practices, such as engaging daily in regular prayers; but why should veiling persuade politicians of women's loyalty to the party even external pressures for the veiled are not very high? Even those lacking the corresponding beliefs may find it expedient to afford to veil and mimic political preferences they do not have.

There is however a difference between secular political insignia and veiling, which we may call viscosity: political insignia are typically cheap to acquire - parties themselves often donate them to supporters - and can be put on or taken off as the occasion demands; veiling, by contrast, even if inexpensive to produce and buy, can be expensive to display as in order to be credible qua religious (and hence political) signal it requires consistency. In this regard, veiling is less costly than many religious practices, but it is more costly than simple political insignia for taking it off would reveal the falsification - once a woman is seen veiling, she cannot, except in anonymous environments, unveil publicly without raising questions about her true piety. Veiling carries a public commitment, and this affords veiling some persuasive weight. Hence, while by itself is a weak signal of genuine religiosity - it may fail to persuade an imam or a pernickety pious wouldbe spouse - it is just reliable enough as a signal of loyalty to a political movement, more so than secular insignia could be.

To summarise, we argue that veiling is a religious practice that can work well as a screening device in a political context. On the one hand, due to its viscosity veiling is costly enough to deter those who would only pretend to be prepared to vote for a religious political party from 
using it. On the other hand, by not being too costly veiling can become widely adopted. In addition, unlike other practices, such as praying or charitable donations, veiling is easier to observe. Thus, screening clients on veiling is efficient and gives political parties the chance to still pursue a popular majority, which would be denied if they screened on more expensive signals.

Our theoretical framework has the potential to be applied to other behaviours that can work as political signals - for men, one can think of beards and regular mosque attendance, particularly to the Friday prayer. Data on these other religious practices however are, regrettably, scarce. To check the solidity of our reasoning we develop a formal model which demonstrates how moderately costly and highly visible practices work best as signals of loyalty to religious parties (online appendix A).

Our theoretical framework has some ancestors that deserve to be mentioned. In Iannacone's (1992) religious club good model costly religious acts work as signals of commitment to the religious organisation and the organisation uses those signals to screen out less committed members and free-riders. The main difference of this model with ours is that religious organisations (e.g. sects and communities) can require more stringent signals from their members, for a certain number of committed members would suffice for the community to thrive. Political parties, by contrast, need to solve the screening problem of identifying loyal clients while at the same time maximising popular votes. This makes the free-rider problem experienced by political parties different from the one local religious communities experience.

Chen (2010) builds on Iannacone's model and shows that economic shocks increase the intensity of religious involvement. Chen argues that religious involvement works as social insurance against hardship: the pious who are in need can turn to their religious community for help. 
Similar to ours Chen's work too demonstrates the important role social insurance plays in religious involvement. In our case, however, we have a more tangible insurance provider than the "community", namely the local authorities and the AK Parti.

Carvalho (2013) proposes a formal model of veiling, which is tested empirically by Aksoy and Gambetta (2016). In Carvalho (2013) veiling is modelled as a commitment device rather than signalling. Women may veil to bind themselves so that they are unable to misbehave even if they were inclined to. In this sense, commitment is an inward-looking self-control motive, although it can still inform the community of the piety of the women.

Finally, the social psychological literature distinguishes between extrinsic and intrinsic religious orientations (Allport and Ross 1967). Those with the former use religion for attaining instrumental goals (status, security, power, self-justification etc.), while those with the latter "live" the religion. Signalling motives in our case can be seen as a subset of extrinsic motives. In contrast with a social psychological approach, here we test whether a shift in external macro conditions increases the incentives for extrinsic religiosity.

\section{Hypotheses}

By applying these insights on political signalling using religious behaviour to Turkey's Islamist AK Parti, we derive a set of hypotheses. We will describe in detail the Turkish context and the AK Parti politics after formulating our hypotheses. We predict that:

H1: The likelihood of veiling is higher in areas where the local authority is under the AK Parti's control.

This does not imply that religiosity itself increases under the AK Parti. In fact, we predict from a signalling perspective that that less visible or more costly religious practices such as performing the regular daily prayers (namaz) are unaffected by the AK Parti governance. 
H2: The effect of the AK Parti predicted in H1 does not extend to more costly or less observable religious practices, such as regular praying.

Note that the payoffs for the client, such as access to jobs, welfare, and social assistance should be more beneficial for the poor (Calvo and Murillo 2004). Hence, we expect that:

H3: The effect of the AK Parti on veiling predicted in HI are stronger the poorer the women are These hypotheses are about the client's signalling behaviour. We further predict that the AK Parti selects on religious signals in distributing the patronage premium. Local-level data on the party's patronage decisions are scarce, but our datasets nevertheless include one measure which can reveal AK Parti's patronage: access to free healthcare. We will describe Turkey's healthcare and local welfare provision system in the next section. In short, we expect to find the AK Parti to be more efficient than its secular counterparts in providing local welfare. This is because the central and local AK Parti governments work in tandem, the central government distributes resources strategically to its local municipalities, and the local welfare system the AK Parti has developed relies on religious charity motives, which give the AK Parti an edge over secular parties. We thus expect that:

H4: the likelihood of having the general health insurance versus no insurance is higher in areas where the local authority is under the AK Parti's control.

Our model also predicts that a religious signal such as veiling increases the chances of access to patronage in AK Parti municipalities.

H5: veiling is positively associated with access to free healthcare in AK Parti municipalities.

We drive the hypotheses above from the signalling perspective. After presenting the tests of these hypotheses, we will provide additional analyses using which we will try to disentangle the 
signalling motives from community pressure and conformism. Let us now describe in detail the Turkish context and the evolution of AK Parti's clientelistic local welfare system.

\section{Evolution of clientelism in Turkey under AK Parti}

Since Atatürk founded it in 1923, modern Turkey had been secular. Atatürk set a modernizing agenda that emphasized economic development, Westernization, and secularization in all domains of social life. This "Kemalist" vision, aimed at relieving the individual from the pressures of tradition and religion (Mardin 2010), was embraced by urban denizens while most of the population remained marginalized, poor, and indeed pious (Yavuz 2000). Practicing Muslims found themselves discriminated against and rejected by the ruling elite (Somer 2017).

The rise of the AK Parti (Justice and Development Party) in 2002 marked an end to statecontrolled secularization. The AK Parti represents continuity in political Islam, but with the scale of its power it signifies a paradigm shift (Aksoy 2016). Under Recep Tayyip Erdoğan's leadership, the AK Parti gained a parliamentary majority in 2002 and captured most Turkey's municipalities in its first local elections in 2004. Since then the AK Parti has consolidated its political power.

Change however did not happen immediately. Until around 2010, many believed the AK Parti to be a modernizing force that while giving a voice to the marginalized poor and pious, it also promoted democratization and prosperity. Indeed, the early terms in power of the AK Parti were marked by rapid economic development (Rodrik 2012). Gradually, but more forcefully after the recession of 2009, the AK Parti changed course boosting the presence of Islam in public life and curtailing Turkey secular tradition (Kuran 2018): it reversed the ban on veiling at public universities and offices, introduced restrictions on alcohol, erected new Mosques, supported 
religious vocational schools (Imam-Hatip), and increased four-fold the budget of Turkish Presidency of Religious Affairs (TPRA).

The causal force we expect to affect veiling came into full realisation six years after the elections of 2004. The effect of the recession on the AK Parti became apparent in the 2009 elections in which the party lost more of its mayoralties than it won new ones, and its vote fell by three points to 39\%. After these warning signs the party increased its Islamic tone and policies, and succeeded in overturning the effects of the recession: in 2010 it won a remarkable $58 \%$ of all votes in a constitutional referendum; and in the 2011 general elections it obtained a comfortable majority in parliament for the third time after receiving a whopping $49.83 \%$, almost twice the vote share of the runner up (CHP with 25.98\%). We thus expect to find evidence for $\mathrm{H} 1$ after 2009, when the "Islamisation" has taken pace.

The Islamisation of the AK Parti is well-captured by two trends. First, the growth of state-funded religious vocational schools (Imam-Hatip): until 2010 the number of Imam-Hatips was stable at around 450; from 2010 to 2012 they increased to 537 and then shot up to 1,452 by 2017 (Figure 1). The students in these schools increased by about 11,700 annually until 2009 , but between 2009 and 2015 the yearly increase climbed up to 67,000 students, a nearly six-fold increase. The Education and Science Workers' Union (Eğitim-Sen) explains this dramatic increase as the result of the generous funding of the Ministry of Education and the conversion of secular schools into religious schools by the government. ${ }^{3}$

\footnotetext{
${ }^{3}$ For the full report (in Turkish) see: http://egitimsen.org.tr/wpcontent/uploads/2017/09/E\%C4\%9Fitimin-Durumu-Raporu-13-Eyl\%C3\%BCl-2017.pdf
} 
Second, the growth after 2005 (Figure 1) of Mosques and religious personnel-administrative and service staff at mosques, Imams, müezzins, and Quran course instructors: Until 2010 the number of Mosques grew by about 700 per year. Between 2011 and 2012 however, as many as 2,000 new Mosques opened (from 82,693 in 2011 to 84,684 in 2012). According to TPRA, the size of religious personnel, stable until 2010, increased sharply between 2010 and 2013 (84,000 to 121,000). After year 2000 the number of female preachers employed by TPRA increased by a staggering $713 \%$, and that of female Quran course instructors increased four-fold. ${ }^{4}$ Although the gender breakdown of the change in religious personnel numbers in Figure 1 is unavailable, it is plausible that women benefited more than men from this increase in religious employment opportunities.

We argue that the "Islamisation" of the country increased the payoffs for the pious, either directly as access to newly available religious personnel jobs and local welfare provision or indirectly through social approval by the religious community. Indeed, since rising to power the AK Parti has launched a capillary charity-based welfare system (Buğra and Keyder 2006). In this system, the poor are assisted with cash, food and fuel, or social security cover, using the funds raised by municipalities and local organizations. Religious motivations are at the centre. NGOs in welfare (such as the infamous Deniz Feneri $^{5}$ ) use Islamic values as to foster charitable giving

\footnotetext{
${ }^{4}$ See (in Turkish)

http://www2.diyanet.gov.tr/DinHizmetleriGenelMudurlugu/KadnveAileyeYonelikCalsmalar/Ka dinVeA\%C4\%B1leyeYonel\%C4\%B1kCalismalar.pdf

${ }^{5}$ See (in English) http://www.dw.com/en/german-court-hands-down-jail-terms-in-islamiccharity-scandal/a-3652266
} 
(Buğra and Keyder 2006). Province- and district-level governments play a vital role in this system (Metin 2011). The "Social Assistance and Solidarity Foundations" organized at the provincial- and district-level are responsible for the distribution of social assistance. Province and district mayors often sit on the board of these foundations. This system gives mayors substantial discretion, which offers ample opportunities for clientelism (Metin 2011). For instance, Umit (2018) analysed the distribution of Istanbul's budget across its provinces and found that the investment plan for 2018 does indeed privilege the AK Parti districts of Istanbul, which receive around 250 million Turkish liras more than non-AK Parti districts ceteris paribus.

The social welfare system is organised locally, but the central AK Parti government too invests strategically. Analysing government's spending across the provinces of Turkey from 2003 to 2014, Cammett, Luca, and Sergenti (2018) find that the central government systematically used the allocation of social and economic budget expenditures to channel resources (e.g. conditional cash transfers) to hotly contested districts in order to attract new voters to the AK Parti.

Given the increasing power of the AK Parti and the expansion of local welfare provision, the incentives to become a client of the AK Parti or pro-AK Parti organizations also increased. As the pro-government Confederation of Public Servant Trade Unions (Memur-Sen) proudly announced, its membership shot up by almost 18 -fold from 47,871 in 2002 to 836,505 in $2015 .{ }^{6}$

${ }^{6}$ See (in Turkish) http://www.memursen.org.tr/show_file.php?attachid=293 
Figure 1. Upper panel: number of Mosques and religious personnel by year (data source: Turkish Presidency of Religious Affairs); lower panel: annual number of state funded religious high schools (Imam-Hatip) and students in these school (data source: Education and Science Worker's Union (Ĕ̈itim-Sen).
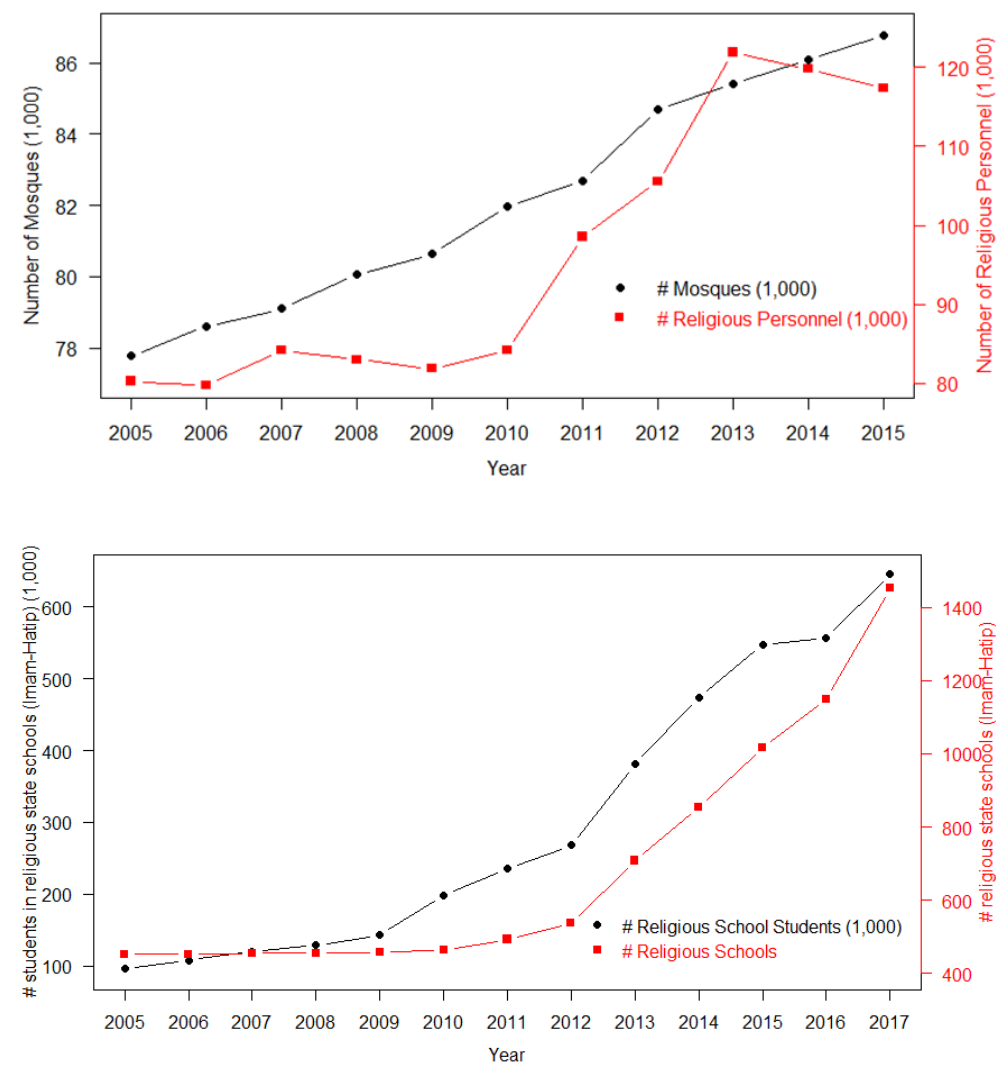

It is important to describe Turkey's General Social Security (GSS), also known as the "green card" in detail. GSS is only one form of social assistance provided by local authorities. AK Parti's social assistance programme comprises many elements such as conditional cash transfers, prenatal training, housing and food aid. Detailed data on these forms of local welfare are unavailable (Buğra and Keyder 2006), we therefore have to rely on GSS not only as a measure of free health care but as an indirect indicator of many other forms of welfare that can be dispensed clientelistically. 
The green card program was started in 1992 to provide free health care to poor citizens. In 2003 AK Parti expended it so that citizens lacking other forms of social security and earning less than a certain threshold became eligible for free hospital services and prescription medicines. Importantly, green card applications need to be approved by a local administrative council, which comprises the local governor and other officials appointed by the central government. The council is required to gather information on applicants' income. The council also aims to collect information on the applicant's informal sources of income. How far the council pushes this scrutiny is rather flexible. Yoltar's (2009) ethnographic study shows that in deciding eligibility green card officers can resort to as vague criteria as being a "fine citizen deserving of the state's compassion".

The findings of Kemahlioglu and Bayer (2020), who have analysed the diffusion of green cards across Turkey, lend clear support to our Hypothesis 4. Using data from the Ministry of Health, which differ from our data, they conclude "that municipalities whose mayors are affiliated with the national incumbent party, the AKP, receive more green cards because local government resources are used to build stronger local party organizations, which then help reach citizens that the incumbent party wants to target" (p. 2) and that "local party organizations, which are stronger in AKP-controlled municipalities, helped the central government bureaucracy identify such voters, aided them in applying for benefits, and, hence, increased the number of green cards in areas controlled by AKP co-partisans.” (p. 4). In short, local organisations and authorities have large discretion on whom to deny the green card and to whom to dispense it, either by encouraging individuals to apply or by taking advantage of flexible eligibility criteria. This enables vast opportunities for clientelism. 
To test our hypotheses, we exploit a natural experiment made possible by the first local (mayoral) elections of the AK Parti in 2004. In 2004, 20 parties and independent candidates competed for 81 mayoralties at the province centres (II), about 1,000 mayoralties at the lowerlevel district centres (İlçe) and for about 2,000 lowest-level offices. Mayors are elected by a firstpast-the-post system. This enables us to compare provinces which were narrowly won by the AK Parti with those narrowly won by a non-Islamist party. In 2004 the AK Parti obtained 42 percent of all votes, followed by the centre left secular CHP (Republican People's Party) and the ultranationalist right-wing MHP (Nationalist Movement Party) which secured respectively 18 and 10 percent of all votes. There were two other Islamist parties, Saadet (Felicity Party) and BBP (Great Union Party). But Saadet and BBP received only about 4 and 0.4 percent of the votes respectively and neither could win any province-level seats. Consequently, we will use AK Parti rule and Islamic governance interchangeably. While we focus on the 2004 mayoral elections, as they were AK Parti's first, we will also analyse how the results of the 2009 mayoral elections affected our findings.

\section{Data, variables, descriptive statistics}

We match three surveys - Turkey's 2003, 2008 and 2013 Demographic and Health Surveys (henceforth TDHS03, TDHS08 and TDHS13) - with the election results. All three surveys provide a representative sample of Turkish households, but only women at reproductive ages (15-49) were interviewed. In 2003 and 2008 only women who were ever married whereas in 2013 all women were interviewed. The sample sizes are 8,075, 7,405, and 9,746 in 2003, 2008, 
and 2013, respectively. The response rates were consistently above $90 \%{ }^{7}$. The surveys report the province of the respondent but not lower level geographical units. Consequently, we could match electoral results with respondents at the provincial level.

Veiling is a binary variable: whether the respondent covers her head regularly outside the home. We also use a measure of whether the respondent performs the five-times-a-day prayer rituals (Namaz), a less observable and more costly religious behaviour. Veiling is measured in all waves, prayer in 2008 and 2013 only. The key independent variable is the AK Parti's win/lose margin in a province in 2004, the difference between the vote share of the AK Parti and that of the largest remaining party in the province main centre or the metropolitan municipality. In some analyses we will use an "Islamic District Ratio" which is the proportion of lower-level district municipalities in a province won by the AK Parti in 2004.

We further use two electoral variables (from TurkStat) for robustness checks: the provincial level vote share of the Virtue Party (Fazilet) which is the predecessor of the AK Parti in 1999 to measure the local support for political Islam before 2004 and the 2009 mayoral election results.

As controls, we use age and education (in years), occupational status (employed or not), marital status (married, divorced, single), ethnicity per respondent's mother tongue (Turkish, Kurdish, Arabic, and other), urban or rural residence, the ideal number of children a woman wants, a household wealth calculated by the survey designers, and a composite indicator that captures

\footnotetext{
${ }^{7}$ All surveys employ a weighted, stratified, multi-stage cluster sampling approach. For further details see Hacettepe University Institute of Population Studies (2008-2014).
} 
gender norms and values (see online appendix D). We also use the type of health care coverage (or no coverage) of the respondent.

Table 1 presents descriptive statistics for the variables. In $200375 \%$ and in $200876 \%$ of ever married women cover their head when outside the home, whereas in $201373 \%$ of ever married women do so. However, in 2013 ever married women are on average more educated and more likely to be employed than in $2008 / 2003$. When all those factors are accounted the difference between 2008 and 2013 (difference $=0.01, \mathrm{z}=1.02, \mathrm{P}=0.311)$ and between 2003 and 2013 (difference $=0.02, \mathrm{z}=1.43, \mathrm{P}=0.158)$ disappear. Never married women sampled in 2013 are much less likely to veil (41\%) than ever married women.

Figure 2 shows the distribution of the 2004 AK Parti win/lose margin and veiling across the 81 provinces. 58/81 of provinces are won by the AK Parti in 2004. Also, in 59 provinces the AK Parti either won or lost by a wide absolute margin. The Regression Discontinuity Design is based on the provinces $(\mathrm{N}=22)$ where the win/lose margin is low. The multilevel regression and difference-in-difference analysis are based on all provinces. 
Table 1: Descriptive statistics for key variables.

\begin{tabular}{|c|c|c|c|c|c|c|c|c|}
\hline & \multicolumn{2}{|c|}{$\begin{array}{c}2003 \\
\text { Ever married } \\
(\mathrm{N}=8,075)\end{array}$} & \multicolumn{2}{|c|}{$\begin{array}{c}2008 \\
\text { Ever married } \\
(\mathrm{N}=7,405) \\
\end{array}$} & \multicolumn{2}{|c|}{$\begin{array}{c}2013 \\
\text { Ever married } \\
(\mathrm{N}=7,219) \\
\end{array}$} & \multicolumn{2}{|c|}{$\begin{array}{c}2013 \\
\text { Never married } \\
(\mathrm{N}=2,526)\end{array}$} \\
\hline & mean & $\mathrm{sd}$ & mean & $\mathrm{sd}$ & mean & $\mathrm{sd}$ & mean & sd \\
\hline Veil & 0.75 & 0.43 & 0.76 & 0.43 & 0.73 & 0.45 & 0.41 & 0.49 \\
\hline Prayer & NA & NA & 0.50 & 0.50 & 0.54 & 0.50 & 0.35 & 0.48 \\
\hline Age (yrs) & 33.70 & 8.41 & 34.08 & 8.39 & 34.81 & 8.06 & 20.84 & 6.28 \\
\hline Education (yrs) & 5.39 & 4.03 & 5.62 & 3.94 & 6.46 & 4.18 & 9.85 & 3.34 \\
\hline Married & 0.95 & 0.21 & 0.95 & 0.22 & 0.95 & 0.22 & NA & NA \\
\hline Divorced & 0.02 & 0.13 & 0.03 & 0.17 & 0.04 & 0.19 & NA & NA \\
\hline Widowed & 0.02 & 0.15 & 0.02 & 0.14 & 0.02 & 0.13 & NA & NA \\
\hline Turk & 0.77 & 0.42 & 0.77 & 0.42 & 0.77 & 0.42 & 0.76 & 0.43 \\
\hline Kurd & 0.19 & 0.39 & 0.20 & 0.40 & 0.19 & 0.39 & 0.21 & 0.41 \\
\hline Arab & 0.02 & 0.15 & 0.02 & 0.15 & 0.03 & 0.16 & 0.02 & 0.14 \\
\hline Other ethnicity & 0.00 & 0.00 & 0.01 & 0.09 & 0.01 & 0.11 & 0.01 & 0.09 \\
\hline Ideal \# children & 2.61 & 1.18 & 2.62 & 1.25 & 2.90 & 1.31 & 2.40 & 1.08 \\
\hline Urban & 0.72 & 0.45 & 0.73 & 0.44 & 0.73 & 0.44 & 0.74 & 0.44 \\
\hline Wealth (z-scr) & 0.00 & 1.00 & 0.00 & 1.00 & -0.01 & 1.01 & 0.02 & 0.96 \\
\hline Work & 0.26 & 0.44 & 0.56 & 0.50 & 0.58 & 0.49 & 0.39 & 0.49 \\
\hline Values (z-scr) & 0.00 & 1.00 & 0.00 & 1.00 & 0.05 & 1.00 & -0.14 & 0.96 \\
\hline GSS coverage & 0.10 & 0.30 & 0.18 & 0.39 & 0.13 & 0.34 & 0.15 & 0.36 \\
\hline No insurance & 0.32 & 0.47 & 0.16 & 0.37 & 0.12 & 0.32 & 0.10 & 0.30 \\
\hline
\end{tabular}


Figure 2. Distribution of the AK Parti win/lose margin in 2004 and veiling across the 81 provinces of Turkey.

AK Parti win/lose margin (2004)

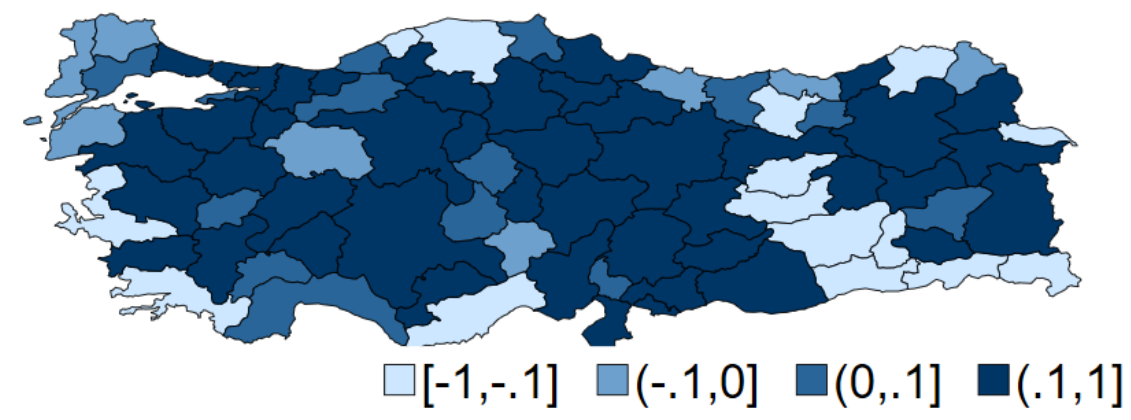

Prevalence of veiling among all women (2013)

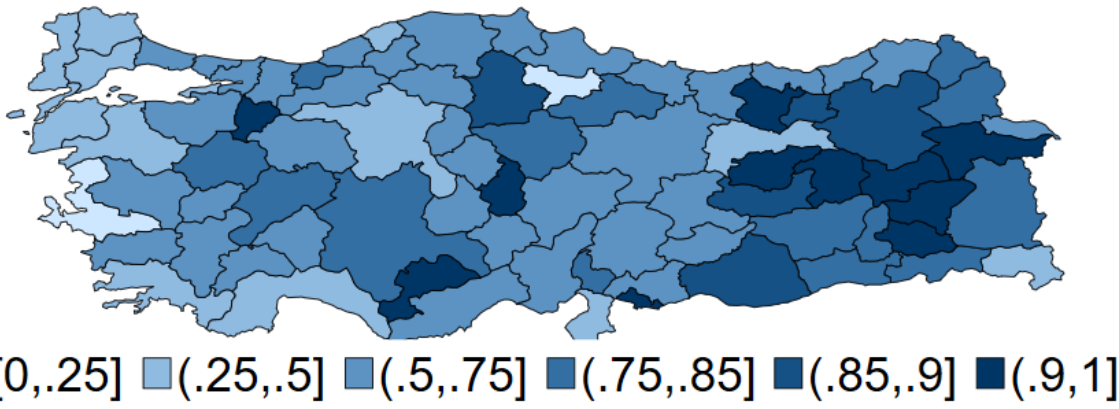

\section{Analysis strategy}

The majoritarian nature of the local elections in Turkey helps us use a strong design, known as Regression Discontinuity design (RDD) (de la Cuesta and Imai 2016; Thistlethwaite and Campbell 1960). In this design, a treatment $t$ is assigned to cases based on a forcing or running variable $x$ such that when $x$ is larger than a cut-off value $c$ the observation receives the treatment $(t=1)$ otherwise control $(t=0)$. In our application, $x$ is the AK Parti's win/lose margin, $c=0$, 
and $t$ is whether the province centre is ruled by the AK Parti after the 2004 elections. Moreover, only cases within $h$ bandwidth around $c$ are included in the analysis.

Our RDD can be written formally:

$E(y)=\alpha_{0}+\alpha_{1}(x)+\alpha_{2}(x t)+\beta t$ with $t=\left\{\begin{array}{l}1 \text { if } x \geq 0 \\ 0 \text { if } x<0\end{array}\right.$ for $-h<x<h$

In equation (1), $\beta$ captures the effect of treatment, namely AK Parti governance. The $\alpha_{1}$ and $\alpha_{2}$ represent the control function of the running variable $x$ (win/lose margin) with a local linear specification, recommended by de la Cuesta and Imai (2016), which can vary below and above the cut-off. The equation is fitted using cases within the $h$ bandwidth around the zero cut-off. ${ }^{8}$ We use the method proposed by Imbens and Kalyanaraman (2012) to calculate an optimum bandwidth value $\hat{h}$ and use it in our main analyses. Below we present robustness checks with alternative bandwidths (Figure 6).

RDD is often characterised as a natural experiment (Gangl 2010, Titiunik 2020). Titiunik (2020) formally defines natural experiments as designs that have the following three properties: "the treatment assignment mechanism is

(i) neither designed nor implemented by the researcher,

(ii) unknown to the researcher, and

(iii) probabilistic by virtue of depending on an external factor" (p. 2).

Titiunik (2020) argues that RDD is a natural experiment as it satisfies all three conditions. In our case, for example, the assignment of an AK Parti governance to provinces are out of our control (condition 1). The second condition is satisfied in RDD too, for, while we know the assignment

\footnotetext{
${ }^{8}$ For a logistic specification with a binary outcome variable, $\mathrm{E}(\mathrm{y})$ is replaced by $\log (\mathrm{p} /(1-\mathrm{p}))$.
} 
mechanism as $x>c$ implies that $t=1$ in equation (1), this is only known conditional on $x$. The probability distribution of $x$ is essentially unknown to us, for there is always an element of chance in the exact vote shares of political parties. Finally, in the small window $h$ around the cutoff $c$, it is plausible to think that treatment assignment is probabilistic due to electoral noise, unpredictability of $x$, and the sharp RD rule that when $x>0, t=1$. In large-scale popular elections there is much unsystematic "noise" - such as accident, illness, weather conditions, and any other random factor that affects the turnout among a few voters. These factors are thought to be sufficient to shift the result of razor-sharp election in either direction (Eggers et al. 2015). Hence, the assumption is that potential outcomes of all confounders are continuous at the cut-off $c$, except $t$. If this assumption is correct, a comparison of the provinces around the threshold will reveal the "causal" effect of the AK Parti rule on the outcome variable $y$.

It is possible to test the above assumption, first by checking whether the pre-treatment variables jump abruptly at the threshold (i.e. by replacing $y$ in equation 1 by pre-treatment variables). Significant differences would invalidate the RDD. Next, McCrary (2008) proposed a density test, which does not require any pre-treatment variable. Sorting around the cut-off, that is some cases being more likely to be just above the threshold, would also invalidate an RDD. But if there is sorting, one would expect to see a discontinuity in the density of $x$. McCrary's test checks density around the cut-off. We carried out both tests (see online appendix B). Importantly, as a placebo test, we find that the 2004 elections had no 'retro-effect' as it were on veiling prevalence in 2003 .

While one can test the underlying assumptions of RDD and disprove them, it is not possible to prove definitively that those assumptions are met. Hence, we validate the main RDD results in two additional ways. First, we use multilevel regressions with random effects for provinces and 
households, and regress veiling on "Islamic district ratio", proportion of districts won by the AK Parti within a province. Second, we use a difference-in-difference analysis testing how veiling changes in a province from 2003 to 2013, and whether this change is different between AK Parti versus non-AK Parti provinces. In both multilevel and difference-in-difference models we control for various key covariates.

We are not alone in applying an RDD to Turkish elections. The pathbreaking study was by Meyersson (2014), who used the 1994 elections and found that Islamist mayors facilitate female educational attainment. Meyersson explains this finding by arguing that Islamist mayors lower the educational entry barriers women experience by, for instance, stretching the veil bans in schools and providing educational facilities to the conservative and poor citizens. Aksoy and Billari (2018) too apply an RDD and show that a local AK Parti rule increases marriage rates and fertility. They explain this by AK Parti's efficiency in providing social welfare and assistance at the local level. This local social welfare system of the AK Parti is key in our theoretical framework. Finally, Çörekçioğlu (2018) shows using an RDD that the AK Parti municipalities hired more female employees after the repeal of the veil ban.

\section{Results}

Using a combination of the RDD detailed above and more conventional regression models we test our hypotheses. We use linear probability models, unless stated otherwise. Results with binary logistic regressions for binary outcomes are qualitatively the same. ${ }^{9}$

\footnotetext{
${ }^{9}$ Full replication material (data and code) are submitted with the manuscript for peer review.
} 
Starting from hypothesis 1, we find that in 2008 an Islamic governance in 2004 has a small and statistically insignificant positive effect on the likelihood of veiling $(\beta$ [marginal effect] $=0.03$, province-level cluster robust S.E. $=0.12, P=0.787$ for the optimal bandwidth of 0.17 ), but in 2013 it does have a very strong positive effect in 2013 ( $\beta$ [marginal effect] $=0.25$, province-level cluster robust S.E. $=0.07, P=0.001$ for the optimal bandwidth of 0.087 ). See Figure 3 for a graphical representation of those effects. This is consistent with a slowly growing effect picking up speed after 2010 when religion came at the forefront in AK Parti's political agenda. As a placebo check we find no significant effect of Islamic governance in 2004 on veiling in 2003 (Figure 3).

We further check what happens in provinces gained by the AK Parti in 2004 but lost to another party in the 2009 elections. We expect that in provinces in which the AK Parti lost in 2009, the effect predicted in Hypothesis 1 should be lower. Once the cause is off, the effect should wane. We find support for this expectation. RD effect of the AK Parti in 2004 on veiling probability in 2013 is about 0.34 in provinces that did not swing away from the AK Parti, while in provinces lost by the AK Parti in 2009 the effect on veiling does not disappear, but is significantly smaller (interaction coefficient $=-0.16, \mathrm{P}=0.022$ ). See online appendix $\mathrm{C}$ for further details.

One could suspect that the effect of AK Parti governance on veiling might be due to selection: more religious and hence veiled women might have immigrated to AK Parti provinces after 2008. There is no evidence for this explanation. Aksoy and Billari (2018) show that an AK Parti governance has no effect on sub-national net immigration of women.

Hypothesis 2 finds support: Islamic governance affects veiling in 2013 substantially, but it does not affect praying significantly neither in 2013 (RDD marginal effect $=0.09, P=0.304$ ) nor in $2008($ RDD marginal effect $=0.02, P=0.898)($ Figure 4$)$. 
Figure 3. Islamic win/lose margin in the province centre in 2004 versus veiling prevalence in the province in 2003,2008 , and 2013 with loess smoother.

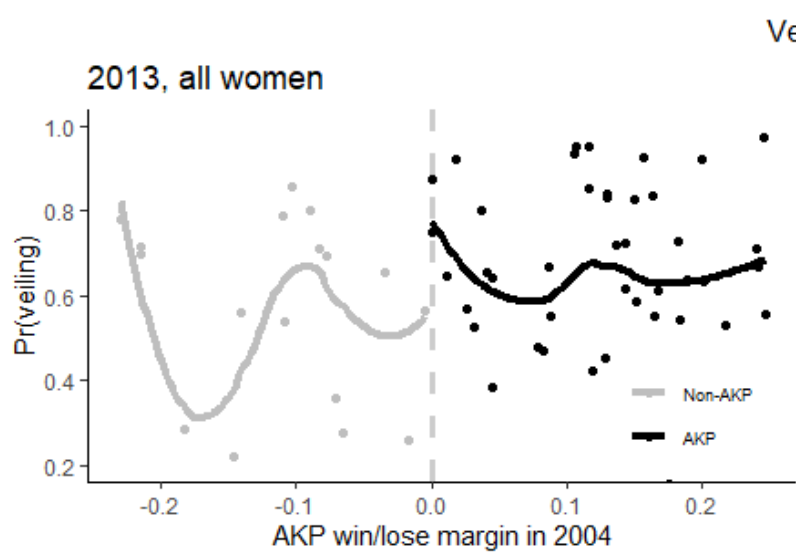

Veiling
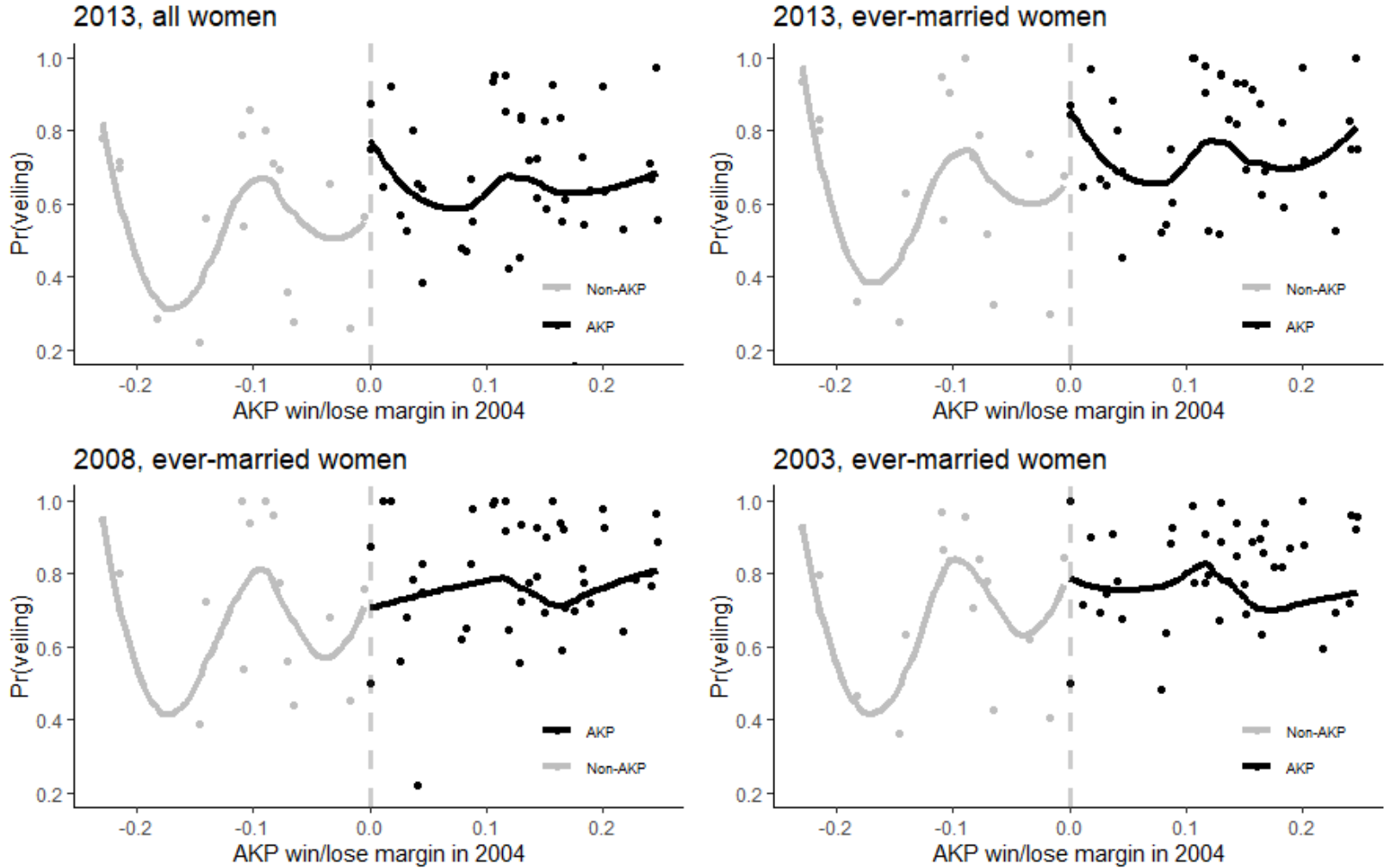
Figure 4. Islamic win/lose margin in the province centre in 2004 and subsequent praying prevalence with loess smoother.
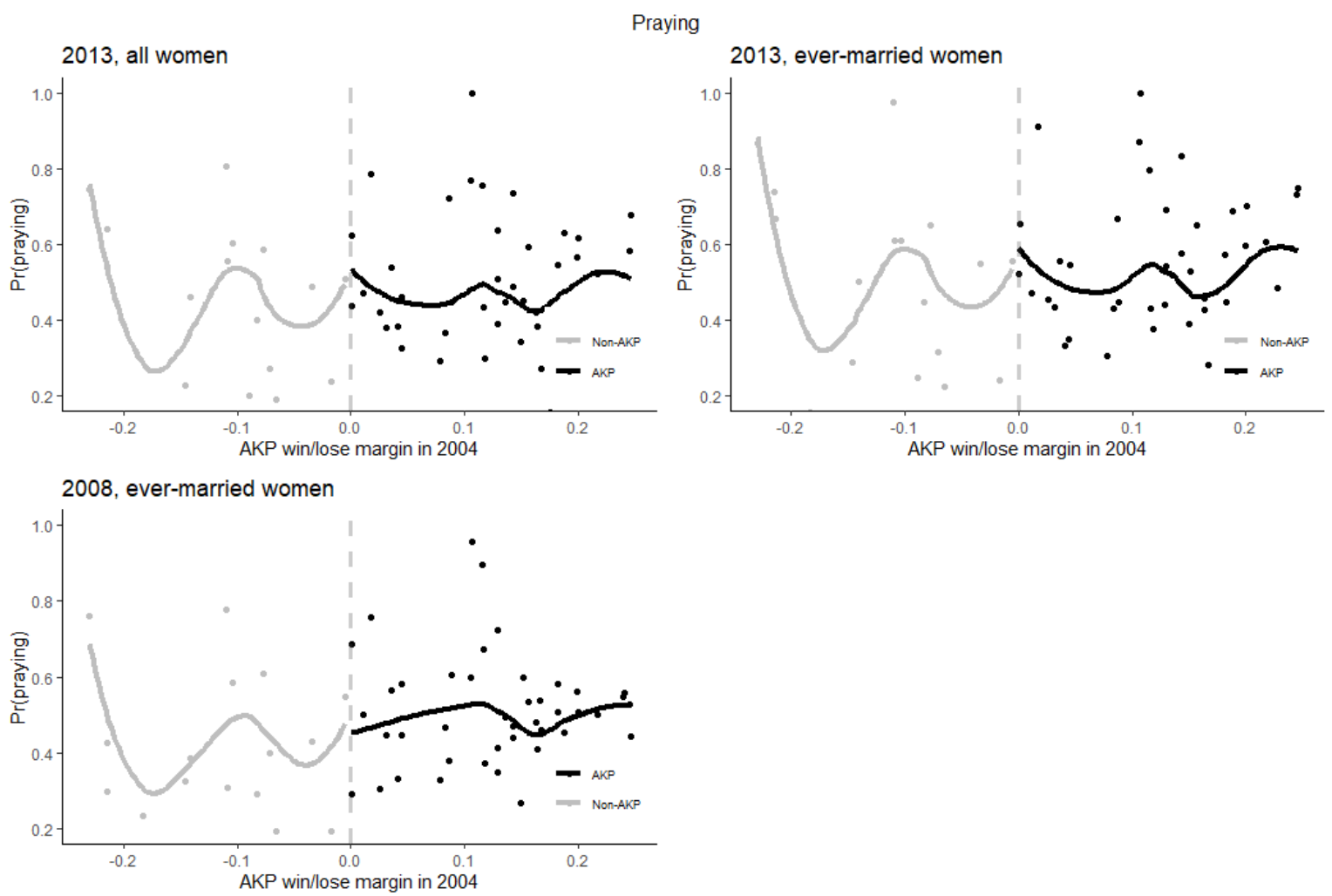

We test hypothesis 3 with an interaction between the treatment indicator and the household wealth (z-score) in the RDD. In addition, we control for nesting within households and provinces with random intercepts. We find that for every standard deviation increase in household wealth, the effect of Islamic governance in 2004 on veiling probability in 2013 decreases by about 6 percentage points (interaction coefficient $=-0.06, P=0.012) .{ }^{10}$

\footnotetext{
${ }^{10}$ We do not find any significant interaction between local Islamic governance and household wealth for veiling in 2008 (interaction coefficient $=0.037, P=0.206$ ) and when random effects for provinces and households were omitted (interaction coefficient $=-0.05, P=0.186$ ).
} 
Hypotheses 4 and 5 concern whether the AK Parti distributes resources disproportionately to its voters and to those who signal religiosity. Figure 5 shows how access to free healthcare (General Social Security coverage, GSS) varies by the AK Parti win/lose margin in the 2004 elections. Supporting hypothesis 4, there is a very strong effect of AK Parti on GSS coverage in 2013 ( $\beta$ $[$ marginal effect $]=0.18$, province-level cluster robust S.E. $=0.08, P=0.032$ for the optimal bandwidth of 0.07). There is a positive RD effect of AK Parti rule on GSS coverage in 2008 which is statistically insignificant $(\beta$ [marginal effect $]=0.11$, province-level cluster robust S.E. $=$ $0.10, P=0.239$ for the optimal bandwidth of 0.19 ). The effect in 2003 (a year before the 2004 elections $)$ is virtually zero $(\beta$ marginal effect $]=-0.03$, province-level cluster robust S.E. $=0.03$, $P=0.270)$.

We also find in line with hypothesis 5 that, conditional on various controls (viz. marital status, education, age, household wealth, employment status, ideal and actual number of children, gender norms and values, urbanicity, ethnicity, survey year fixed effects) being veiled is positively associated with the likelihood of having GSS coverage versus no coverage in AK Parti provinces $($ marginal effect $=.06, \mathrm{~S} . \mathrm{E} .=.02, P=0.022$ ). This result is obtained with a logistic regression model that predicts the probability of having GSS versus having no insurance (see Table 2). Note that this result is not obtained using RDD, so we make no strong claim of causality.

A marginal effect of 0.06 corresponds to a $16 \%$ increase in the probability of having GSS versus no insurance, for the baseline probability of having no insurance is $19 \%$. Note that this result is an outcome of an individual-level analysis rather than province-level. That is, within AK Parti provinces, veiled women have better chances of receiving GSS than unveiled women even after adjusting for household wealth, education, employment status and other covariates. Indeed, 
veiled women could be poorer on average, which could in turn affect the chance of having GSS, so it is important to control for household wealth, education, and employment status in the model. There is also a positive, albeit insignificant association between being veiled and GSS coverage in non-AK Parti provinces (marginal effect $=.05$, S.E. $=.05, P=0.298$ ). Praying is not associated significantly with the probability of having GSS versus no insurance in AK Parti (marginal effect $=0.02, P=0.179)$ and non-AK Parti provinces $($ marginal effect $=0.03, P=$ 0.457). These findings on praying are obtained using the same set of control variables as in Table 2 but excluding veiling.

These findings establish that the AK Parti mayors invest more strongly in social welfare than non-AK Parti mayors and that veiling could increase the chances of access to this welfare, particularly in AK Parti provinces. 
Figure 5. Prevalence of access to healthcare (General Social Security/Green Card) relative to all other forms of insurance by AK Parti win/lose margin in 2004 and by year with loess smoother.
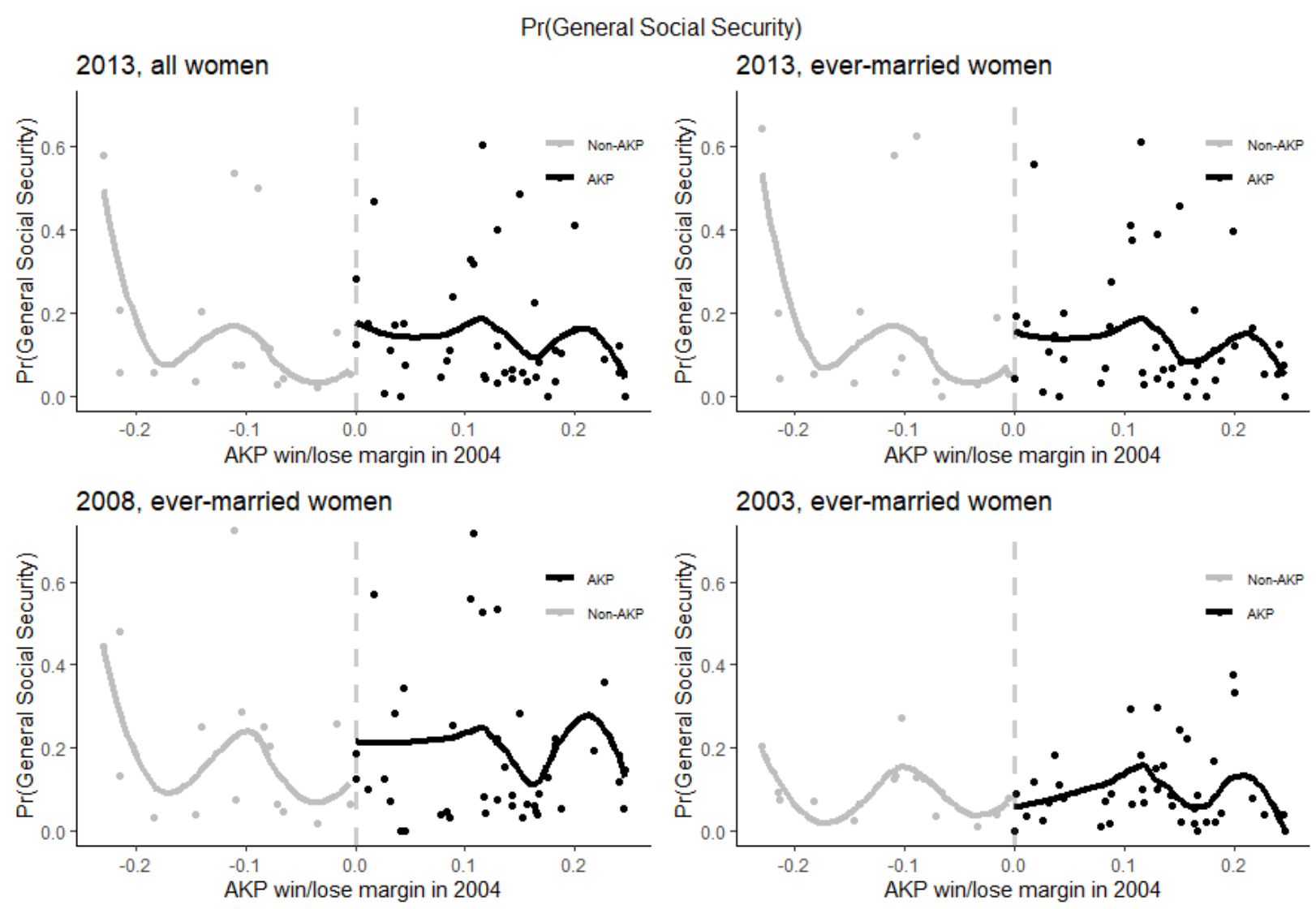
Table 2. Logistic regressions predicting the probability of having General Social Security

(Green Card) vs no health insurance in AK Parti and non-AK Parti provinces. Data:

Turkey's 2003, 2008, and 2013 Demographic and Health Survey.

\begin{tabular}{|c|c|c|}
\hline & AK Parti & Non-AK Parti \\
\hline & Provinces & Provinces \\
\hline Participant veils (binary) & $0.262 *(0.116)$ & $0.234(0.225)$ \\
\hline AKP win/lose margin & $-1.244+(0.684)$ & $-1.133 *(0.556)$ \\
\hline \multicolumn{3}{|l|}{ Year (reference: 2003) } \\
\hline 2008 & $1.314 * * *(0.156)$ & $1.508 * * *(0.232$ \\
\hline 2013 & $1.343 * * *(0.140)$ & $1.614 * * *(0.397)$ \\
\hline Education (in years) & $-0.069 * * *(0.013)$ & $-0.037 *(0.019)$ \\
\hline Age & $-0.028 * * *(0.006)$ & $-0.027 * *(0.010)$ \\
\hline \multicolumn{3}{|l|}{ Marital status (ref: single) } \\
\hline Married & $-0.510 * *(0.189)$ & $-0.094(0.272)$ \\
\hline Divorced & $-0.496 *(0.206)$ & $0.110(0.448)$ \\
\hline Widowed & $0.137(0.372)$ & $0.019(0.599)$ \\
\hline
\end{tabular}

Ethnicity (ref: Turk)
Kurd
$0.516^{* * *}(0.107)$
$0.701 * * *(0.166)$ 


\begin{tabular}{|c|c|c|}
\hline Arab & $0.217(0.170)$ & $0.000(0.330)$ \\
\hline Other & $-0.453(0.445)$ & $0.472(0.482)$ \\
\hline Ideal $\mathrm{N}$ children & $-0.000(0.021)$ & $-0.016(0.043)$ \\
\hline Actual N children & $0.122 * * *(0.023)$ & $0.063(0.047)$ \\
\hline Urban vs rural & $-0.214(0.134)$ & $-0.068(0.175)$ \\
\hline Wealth & $-0.042(0.058)$ & $-0.138+(0.078)$ \\
\hline Traditional values & $-0.064 *(0.030)$ & $-0.027(0.079)$ \\
\hline Employed & $-0.248 * * *(0.066)$ & $-0.237+(0.129)$ \\
\hline _constant & $0.157(0.270)$ & $-0.727+(0.478)$ \\
\hline$N$ (individual) & 5103 & 1532 \\
\hline Log likelihood & -3113.993 & -923.39 \\
\hline
\end{tabular}

$\overline{\text { Cluster (province) robust standard errors in parentheses; }+\mathrm{p}<0.1, * \mathrm{p}<0.05}, * * \mathrm{p}<0.01, * * *$ $\mathrm{p}<0.001$

In the rest of the paper we will subject both our theoretical interpretation and our empirical results to severe scrutiny. First, we will impose a large number of checks on our results. Second, we will test the implications of alternative explanations vis a vis the implication of our model. 


\section{Robustness checks}

\section{Validating RDD: Multilevel regression and difference-in-difference}

We report here the results of a multilevel regression model, which may suffer from internal validity issues, but has arguably greater externally validity than RDDs because it uses all observations. In this analysis, we also measure AK Parti's power in a province in a more elaborate way. Rather than measuring if AK Parti won or lost the province centre, we calculate an "Islamic district ratio", defined as the proportion of districts in a province ruled by the AK Parti after 2004. The results of this conventional analysis are in line with our RDD results (see Table 3). Islamic district ratio in 2004 is associated with veiling positively (in 2013 marginal effect $=0.19$, S.E. $=0.073, \mathrm{P}=0.01$, in 2008 marginal effect $=0.14$, S.E. $=0.069, \mathrm{P}=0.042$ )

Table 3: M1 and M2: three-level (individuals in households in provinces) random effects linear probability regression predicting $\operatorname{Pr}$ (veiling) in 2013 and in 2008. M3: difference-indifference logit model predicting probability veiling in 2003, 2008, and 2013; fixed-effects for provinces included; standard errors are robust to clustering in province.

\section{M1 \\ M2 \\ M3}

\section{3}

Islamic district ratio in 2004

AKP win/lose margin

$-0.020(0.077)$

$0.189^{* *}(0.073)$

$0.140 *(0.069)$

Year (reference: 2003)

\section{8}

$0.065(0.071)$ 
$\mathrm{AKP} \times$ Year interaction

\author{
$\mathrm{AKP} \times 2008$ \\ $\mathrm{AKP} \times 2013$ \\ Age
}

Education (in years)

Marital status

Married

Divorced

Widowed

Ethnicity (reference: Turk)
$0.001(0.001) \quad-0.002 * * *(0.001) \quad-0.014 * *(0.004)$

$-0.026 * * *(0.001) \quad-0.037 * * *(0.001) \quad-0.190 * * *(0.009)$

(ref: single) (ref: widowed)

$0.204 * * *(0.013) \quad-0.044(0.030) \quad 0.882 * * *(0.102)$

$0.024(0.026) \quad-0.240 * * *(0.038) \quad-0.122(0.171)$

$0.247 * * *(0.038)$

\begin{tabular}{|c|c|c|c|}
\hline Kurd & $0.011(0.015)$ & $-0.008(0.015)$ & $0.152(0.143)$ \\
\hline Arab & $-0.061+(0.032)$ & $-0.162 * * *(0.035)$ & $-0.672(0.558)$ \\
\hline Other & $-0.118 * *(0.039)$ & $0.042(0.050)$ & $-0.464 *(0.234)$ \\
\hline deal $\mathrm{N}$ children & $0.029 * * *(0.003)$ & $0.019 * * *(0.004)$ & $0.268 * * *(0.023)$ \\
\hline Actual $\mathrm{N}$ children & $0.007+(0.003)$ & $0.017 * * *(0.003)$ & $0.304 * * *(0.028)$ \\
\hline Urban vs rural & $-0.011(0.012)$ & $-0.058 * * *(0.011)$ & $-0.368 * * *(0.104)$ \\
\hline Nealth & $-0.072 * * *(0.006)$ & $-0.044 * * *(0.005)$ & $-0.347 * * *(0.034)$ \\
\hline
\end{tabular}




\begin{tabular}{|c|c|c|c|}
\hline Traditional values & $0.050 * * *(0.004)$ & $0.048 * * *(0.005)$ & $0.405^{* * *}(0.030)$ \\
\hline Employed & $-0.052 * * *(0.009)$ & $-0.046 * * *(0.009)$ & $-0.263 * * *(0.053)$ \\
\hline _constant & $0.521 * * *(0.047)$ & $1.008 * * *(0.054)$ & $0.267(0.169)$ \\
\hline Province fixed-effects & & & $\begin{array}{l}\text { YES (suppressed } \\
\text { for brevity) }\end{array}$ \\
\hline
\end{tabular}

Random part:

\begin{tabular}{llll}
\hline sd(province) & $0.117 * * *(0.011)$ & $0.108 * * *(0.011)$ & \\
sd(household) & $0.178 * * *(0.008)$ & $0.193 * * *(0.016)$ & \\
sd(individual) & $0.341 * * *(0.004)$ & $0.294 * *(0.011)$ & \\
\hline$N$ (individual) & 9665 & 7241 & 20932 \\
Log likelihood & -4500.089 & -2760.598 & -8367.278
\end{tabular}

Standard errors in parentheses; $+\mathrm{p}<0.1, * \mathrm{p}<0.05, * * \mathrm{p}<0.01, * * * \mathrm{p}<0.001$ 
We further report a difference-in-difference analysis. We probe how veiling frequency changes in a province between 2003, 2008, and 2013, and whether the change is different between provinces won by the AK Parti versus provinces lost by the AK Parti in 2004. In a logistic regression we include dummies for 2008, 2013 and their interactions with a dummy for AK Parti governance. We also control for province fixed-effects and other variables (see Table 3, M3). Results show that in non-AK Parti provinces, veiling did not change significantly in 2008 (logit coefficient $=-0.022, \mathrm{P}=0.836$ ) and in 2013 (coefficient $=-0.21, \mathrm{P}=0.100)$ compared with 2003. However, the difference between 2003 and 2013 was significantly different in AK Parti provinces than the same difference in non-AK Parti provinces (interaction coefficient $=0.42$, S.E. $=0.17, \mathrm{P}=0.011)$. In fact, in AK Parti provinces, veiling is estimated to be higher (0.43 0.20 ) in 2013 than in 2003 (sum of the coefficients $=0.21, \mathrm{P}=0.050$ ). This analysis shows that from 2003 to 2013 (before and after the treatment), controlling for the covariates listed above, veiling increased in AK Parti provinces whereas it decreased in non-AK Parti provinces, corroborating our RDD results.

\section{Robustness to RDD specification}

We carried out several robustness checks some of which we summarise here (full details in the online appendix). The RD effect on veiling in 2013 remains virtually unchanged after controlling for several key covariates. Support for political Islam before the 2004 elections does not affect the effect of the 2004 elections. We also carried out 20 placebo cut-off tests, which use a nonzero cut-off value $c$ for the AK Parti win/lose margin (table B2 in appendix). We estimated the main RD effects using Cattaneo et al.'s (2019) bias-corrected and robust method which resulted in very similar estimates as those reported above (with the Cattaneo et al.'s method the RD effect 
on veiling in 2013 is estimated as .30, S.E. $=0.08, P<0.001$ and on green card coverage in 2013 as .18, S.E. $=.08, P=0.028)$.

Finally, Figure 6 shows the robustness of the estimated RDD effects for various outcome variables for a set of different bandwidths including the optimal bandwidth. The significant RDD effect obtained for the outcome variable veiling in 2013 remains positive, large, and statistically significant for most alternative bandwidths. Insignificant effects remain insignificant in all cases, except for praying (namaz) in 2013 for a very small bandwidth. 
Figure 6: Robustness of RDD effect estimate with respect to bandwidth selection, red lines are optimal bandwidths, $95 \%$ Confidence intervals are given.
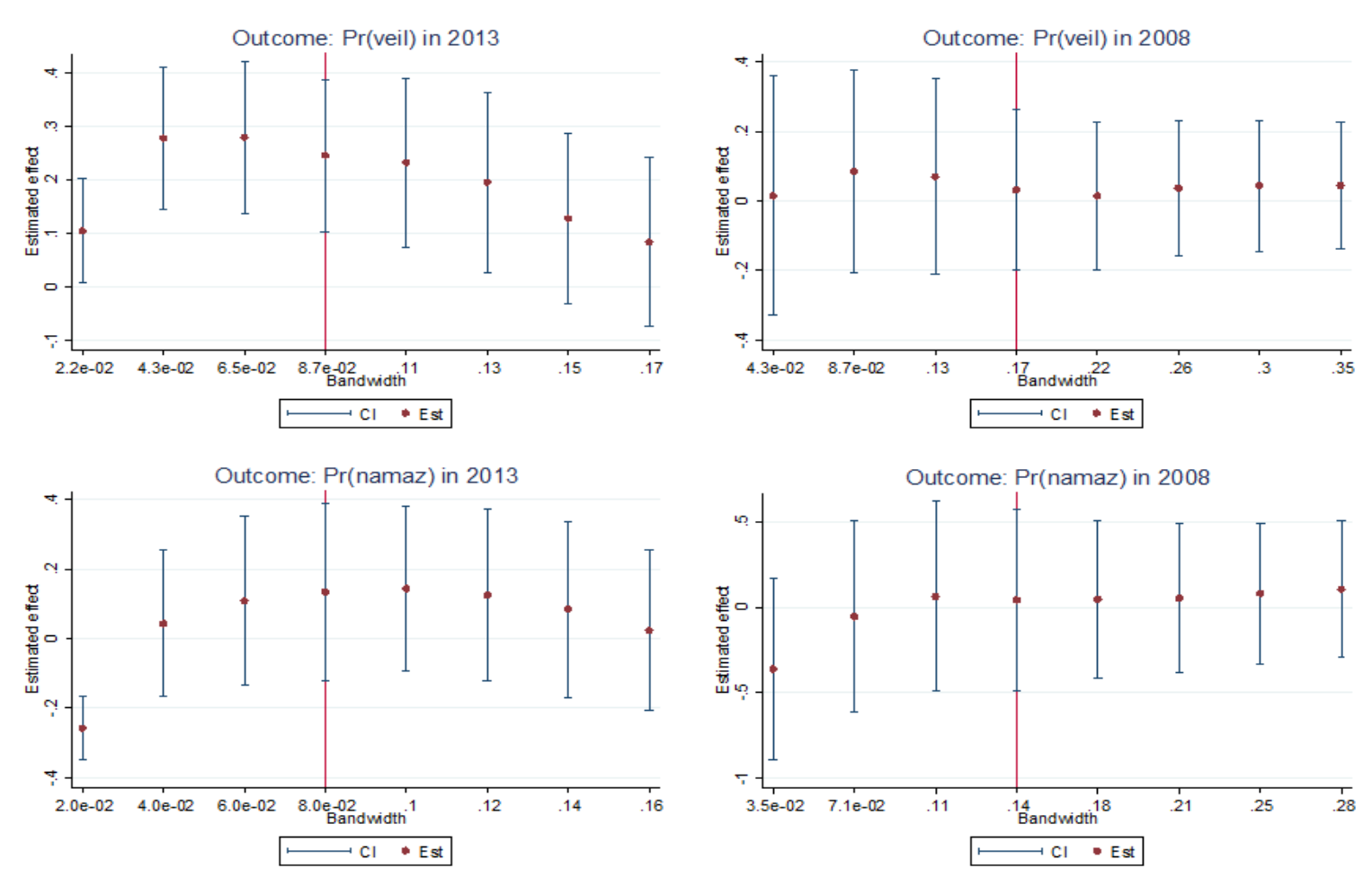

\section{Alternative explanations?}

We find support for all five hypotheses. We interpret these effects as outcomes of a signalling mechanism that drive women to veiling in AK Parti provinces. There may be other mechanisms that could explain these findings. One can argue that people may experience an increase in genuine piety, driven for example by a sense of enhanced group identity in regions in which the Islamist party improved pastoral care. If that were the case, we would expect a positive effect of AK Parti governance on praying too - there is evidence that real piety is associated positively with an array of religious practices including praying (Aksoy and Gambetta 2016). As we noted above, however, we do not find a significant effect of AK Parti on praying. 
Another alternative mechanism we discussed above is conformism with the mores of one's community: community or normative pressures can spread through local networks, increase the number of veiled women to the point of inducing even women who are less religious to veil. To test whether conformism matters we carry out the following three analyses. First, we test whether the AK Parti effect on veiling in 2013 in our RDD is stronger in provinces which had a high veiling prevalence ten years earlier, in 2003. If the effect were driven by adaptation to community customs and in response to the consequent normative pressure, one would expect this effect to be stronger the higher was the veiling prevalence before the treatment. We find no significant interaction between veiling prevalence in 2003 and AK Parti governance (interaction coefficient: $-.11, \mathrm{P}=0.704)$. Also, controlling for veiling prevalence in the province in 2003 does not affect the estimated coefficient for the AK Parti governance.

Second, to probe more directly the political signalling motive that may draw women to veiling in AK Parti provinces, we analyse how political participation is linked with veiling. We use the likelihood of voting as an indicator of political participation. THDS13 includes a question on whether the participant votes regularly (TDHS08 and TDHS03 do not include the voting question). Figure 7 presents the marginal effects of veiling on the probability of voting in 2013. These marginal effects are obtained after adjusting for key covariates. The effects are qualitatively the same without covariate adjustment. The left-hand panel in Figure 7 provides the marginal effects in AK Parti and non-AK Parti provinces. The right-hand panel in Figure 7 further breaks down the marginal effects between the more and the less religious (based on whether the respondent prays or not). While the differences between the marginal effects in the likelihood of voting between AK Parti and non-AK Parti provinces do not seem statistically significant, we find three important and statistically significant results: veiling in 2013 is 
(i) associated with women's voting in AK Parti provinces;

(ii) not associated with women's voting in non-AK Parti provinces.

(iii) Finally, the veiling-voting association in AK Parti provinces seems driven by the less religious - for the highly religious veiling is not significantly associated with voting.

Third, to study further the possible reasons behind veiling, we use a question asked by KONDA Research and Consultancy to a random sample of individuals in Turkey in 2007 and $2010 .{ }^{11}$ This question probes directly the link between wearing the conservative veil türban (as opposed to the less conservative traditional headscarf) and politics: "In your opinion, by wearing türban rather than traditional headscarves, what do you or others demonstrate". ${ }^{12}$ While not perfect, this question tells us something about how subjects perceive the link between veiling and politics. One of the answer categories is "they show their political tendency / standing". The answer categories also include conformism and social identity as possible reasons. Respondents are instructed to select only one answer.

Table 4 shows the answers broken down by year of the survey and by whether the respondent (or their wife) veils regularly. Unsurprisingly, the most popular answer is "they abide by Islam's dictate". Strikingly, however, the second most popular answer is showing one's political tendency, among both veiled and unveiled respondents. Note that since respondents are asked to choose only one answer category, this finding is even more revealing, for it means that for those who reply "showing one's political tendency" this must be the first answer that comes their mind. If respondents had been given the chance to answer with more than one category, it would be reasonable to expect that some of those who chose other categories, especially the dutiful

\footnotetext{
${ }^{11}$ Further details of the datsets can be found in KONDA (2007 and 2010).

${ }^{12}$ Aksoy and Gambetta (2016) compare türban and the traditional headscarf and show that the former is used for strategic signalling purposes
} 
group who replied "they abide by Islam's dictate", might also have ticked "showing one's political tendency" as their second answer.

Moreover, the proportion of respondents who think türban is worn to show ones' political tendency increased significantly from 2007 to 2010. For veiled respondents the proportion is almost doubled (7.6\% to $14.6 \%$ ) and for the unveiled it increased by almost 50\% (30\% versus 43\%). The difference in the answers between 2007 and 2010 is statistically significant both for the unveiled $\left(\chi^{2}(6)=81.65, P<0.001\right)$ and the veiled respondents $\left(\chi^{2}(6)=140.12, P<0.001\right)$. Interestingly, in 2010 almost no veiled women thought that türban shows conformism to the surrounding (3.7\%) or identity (3\%). This that conformism and identity are not the main drivers of türban, and turban is seen as a signal of political tendency by a sizable number of people.

Figure 7. Marginal effects of veiling on probability of voting in elections and their $90 \% \mathrm{CI}$. The effects are obtained after adjusting for marital status, education, age, wealth, employment status, ideal number of children, gender norms and values, ethnicity, urbanicity, praying, random effects for provinces and households. Left panel: average of 
high and low religious. Right panel: breakdown of the marginal effects of veiling on $\operatorname{Pr}$ (Vote) in 2013 by religiosity.

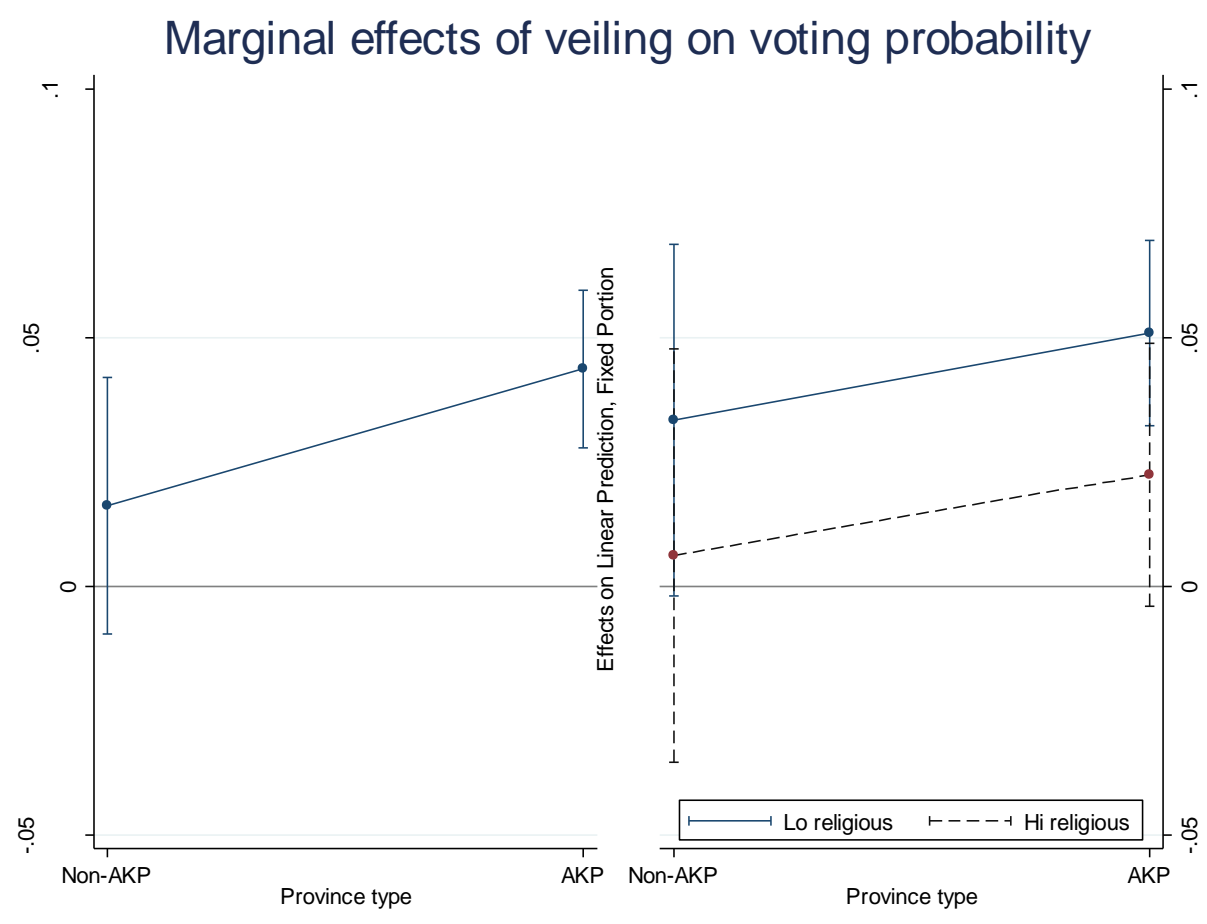


Table 4. Answers to "In your opinion, by wearing türban rather than traditional headscarves, what do you or others demonstrate?" by year and veiling; column percentages in parentheses (Data: KONDA 2007 \& 2010 surveys).

\begin{tabular}{|c|c|c|c|c|}
\hline & \multicolumn{2}{|c|}{2007} & \multicolumn{2}{|c|}{2010} \\
\hline & Unveiled & Veiled & Unveiled & Veiled \\
\hline $\begin{array}{l}\text { They show that they conform to } \\
\text { their social surrounding }\end{array}$ & $115(7.7)$ & $238(7.0)$ & $39(5.6)$ & $63(3.7)$ \\
\hline $\begin{array}{l}\text { They show that they are } \\
\text { virtuous }\end{array}$ & $57(3.8)$ & $95(2.8)$ & $12(1.72)$ & $55(3.2)$ \\
\hline They abide by Islam's dictate & $639(42.5)$ & $2,622(76.9)$ & $222(31.9)$ & $1,188(69.2)$ \\
\hline $\begin{array}{l}\text { They show their political } \\
\text { tendency / standing }\end{array}$ & $450(29.9)$ & $260(7.6)$ & $299(43.0)$ & 251 (14.6) \\
\hline They show their identity & $143(9.5)$ & $79(2.3)$ & $69(9.91)$ & $51(3.0)$ \\
\hline $\begin{array}{l}\text { They protect themselves (2007) } \\
\text { Other (2010) }\end{array}$ & $36(2.4)$ & $61(1.8)$ & $46(6.61)$ & $92(5.4)$ \\
\hline No answer & $63(4.2)$ & $54(1.6)$ & $9(1.29)$ & $18(1.1)$ \\
\hline Total & $1,503(100)$ & $3,409(100)$ & $696(100)$ & $1,718(100)$ \\
\hline
\end{tabular}

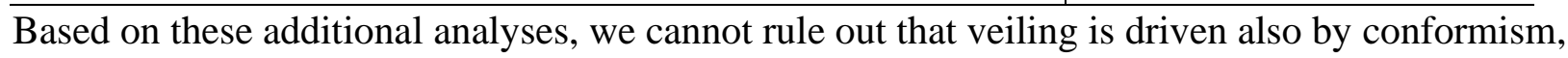
but we can exclude that it is only driven by that: the association between veiling and politics is 
an indication that women's strategic considerations could be an important factor driving our results.

\section{Lift of veil ban in 2013}

There was a major legislation change in Turkey that concerned veiling and which could challenge our explanation: until October 2013 veiling was forbidden in public offices in Turkey, then, on the 4th of that month, parliament lifted the ban. One can argue that this change might have had a stronger positive effect on veiling in AK Parti provinces than in non-AK Parti provinces. Women who always wanted to veil but did not do so because of the ban, now felt legitimised to veil especially in AK Parti provinces. AK Parti provinces may have also been quicker in implementing the repel of the ban than non-AK Parti provinces, resulting in an early difference in veiling frequency. These factors could have brought about the difference we observe in Figure 3 between the AK Parti and non-AK Parti province.

To test this conjecture, we exploit the variation in the interview date in the 2013 wave of TDHS. In 2013 TDHS was fielded conveniently between the 1st of September and end of December. Figure 8 below shows how prevalence of veiling varies by the date on which a respondent was interviewed (centred on the day of lift of veil ban) broken down by whether the province is ruled by the AK Parti. As the figure shows, we do not find any change in the effect of the lift of the ban across the AK Parti and non-AK Patri provinces. Neither the change immediately before and after the day of the lift of the ban nor the change over time varies significantly between AK Parti and non-AK Parti provinces. 
Figure 8. Binned scatterplot of prevalence of veiling by interview date and whether the province is ruled by the AK Parti or not, data source: Turkey's 2013 Demographic and Health Survey.

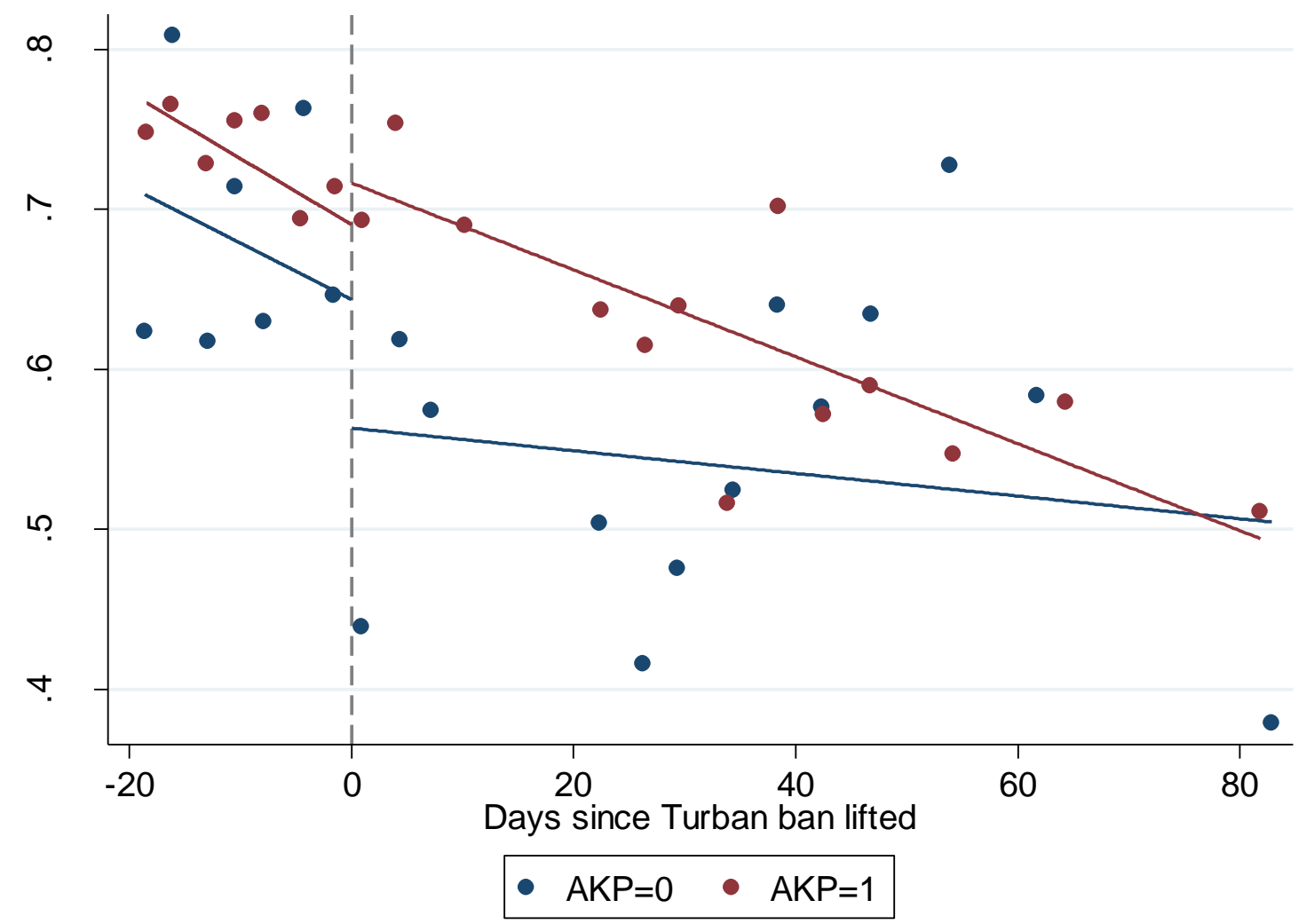

\section{Discussion and conclusions}

In this study, we provide evidence that religious practices respond to incentives. If, for instance, the semblance of piety pays off, even those whose religious beliefs are feeble or absent may choose to mimic religiosity by adopting its outward manifestations. Comparing the provinces with narrow AK Parti wins with those with narrow AK Parti losses, we find that an increase in benefits for the faithful increases veiling without increasing praying. This finding that we derive 
from a Regression Discontinuity Design, survives alternative specifications and statistical models, such as difference-in-difference analysis and traditional multilevel regressions. This finding is compatible with our theoretical model which links voters' signalling of allegiance through perceivable religious practice with the ruling party's payoffs from patronage. Our study thus contributes to the sociology of religion literature showing that observable religious practices have their independent dynamics driven by the pursuit of mundane goals.

We also contribute to the literature on clientelism by developing and testing a theory based on signalling and screening. We think this theory helps us understand better the interplay between politics and religion. We argue how religious behaviours and appurtenances can turn into efficient signals of allegiance for the voters and screening devices for the ruling party. We also argue that political parties with a religious ideology and their voters may have an advantage over their secular competitors in solving a classical problem of clientelism: whom to distribute patronage and whom to exclude.

Our primary aim in our empirical analyses is to test the predictions of this theory. Still, we also scrutinize other mechanisms that are consistent with the finding that women are more likely to veil in AK Parti provinces than in non-AK Parti provinces. A possible alternative is conformism resulting from community pressure and related social norms. An AK Parti win may signal to a nonreligious woman that the community is conservative. This may make her veil in order not to stick out and risk to raise questions about her respectability. We cannot fully rule out that veiling increase that we register in provinces governed by the AK Parti owes also to this conformism effect. In fact, a definitive test of exact mechanisms requires more fine-grained data in the form of qualitative interviews, ethnographic studies, and experimental work. 
Nevertheless, we disentangle signalling from conformism empirically in four different ways.

First, we show that in AK Parti provinces veiling among the nonreligious is strongly associated with voting. Next, we find that veiling prevalence before the elections makes no difference to the effect of AK Parti wins on subsequent veiling - if conformism was the dominant factor one would expect otherwise. Third, we show that at province level an AK Parti majority is associated with more widespread social security coverage, and at the individual level being veiled is associated with a higher chance of having access to social security. And finally, we find that the proportion of veiled and unveiled people who think that women who wear the turban do it to show their political standing has increased significantly from 2007 to 2010, and that very few veiled people think that turban is worn to show conformism or social identity. Taken together, these findings suggest that women's strategic considerations are the driver of our results.

Finally, our study enhances our understanding of political Islam's success in expanding its power in Turkey, a once staunchly secular country. We show that AK Parti and its grassroots organizations may be providing social assistance and welfare very effectively to create selective incentives for the pious and the poor. The rise of the AK Parti in Turkey, thus, resembles the successful ideological and religious movements elsewhere: a strong emphasis on mutual aid, charitable giving, and the provision of basic local services in recruiting and retaining followers.

Here we show how a wafer-thin AK Parti win causes 25 percentage points difference in the likelihood of veiling. It is, however, yet to be seen if this effect is permanent. We find that only outward displays of religiosity rather than more demanding or unobservable religious practices are affected by the AK Parti rule. We also find that in provinces in which the AK Parti subsequently lost, the positive effect of the party on veiling wanes. This suggests that the shift in 
veiling could be a "bubble" bound to burst: should the payoff bonanza set by the AK Parti cease, the difference between AK Parti and non-AK Parti provinces may diminish.

Yet, there is a second possibility. One may choose to flaunt by outward practices an otherwise feeble religiosity for mundane reasons at first. But still, if Blaise Pascal's famous assumption were correct, after some unspecified length of time true religiosity may creep up and eventually align itself to the outward displays of it. ${ }^{13}$ As the great $13^{\text {th }}$ century Muslim poet Rumi put it, "Appear as you are. Or be as you appear." The theory of cognitive dissonance reduction would predict such an outcome (Festinger 1957; Kuran 1995). It predicts paradoxically that if the threat of punishment for having a certain view or the rewards for changing it publicly are large then the person is less likely to change her private views because modifying the public view is fully justified by the large size of the reward or punishment. By contrast, where the actions initially misaligned with beliefs are more freely chosen, move forward by short steps and are induced, rather than by dramatic shifts, by small payoffs or punishments then private beliefs are more likely to change to match the public view. The second condition seems to fit our case: women do not receive a dramatic punishment or reward if they do or do not veil, at least not immediately, and are free not to do it. So the cognitive dissonance reduction prediction would be

${ }^{13}$ See Pascal's Pensée 250: "The external must be joined to the internal to obtain anything from God, that is to say, we must kneel, pray with the lips, etc., in order that proud man, who would not submit himself to God, may be now subject to the creature. To expect help from these externals is superstition; to refuse to join them to the internal is pride." (www.samizdat.qc.ca/arts/lit/Pascal/Pensees_English.pdf) 
that in order to justify what they do, freely and for no great benefit, veiled women are more likely to align their private beliefs to their public ones, and the increase in any initially opportunistic religiosity may eventually lead to a genuine increase in religiosity.

\section{References}

Aksoy, Ozan. 2017. "Motherhood, sex of the offspring, and religious signalling.” Sociological Science 4, 511-527

Aksoy, Ozan. 2016. "Regression discontinuity diagnostics reveal statistical anomalies in Turkish elections." Electoral Studies 44: 284-292.

Aksoy, Ozan, and Francesco C. Billari. 2018. "Political Islam, marriage, and fertility: Evidence from a Natural Experiment." American Journal of Sociology 123(5):1-45.

Aksoy, Ozan, and Diego Gambetta. 2016. "Behind the veil: the strategic use of religious garb." European Sociological Review 32(6):792-806.

Allport, Gordon .W. and Ross, J. Michael. 1967. Personal religious orientation and prejudice. Journal of Personality and Social Psychology, 5(4), p.432.

Baroncelli, et al. 2008. Rickets in the Middle East: role of environment and genetic predisposition. Journal of Clinical Endocrinology \& Metabolism, 93(5): 1743-1750.

Berman, Eli (2011) Radical, Religious, and Violent: the New Economics of Terrorism, Massachusetts MIT.

Blaydes, Lisa. 2014. "How Does Islamist Local Governance Affect the Lives of Women?" Governance 27(3):489-509.

Brünig, Bianca and Fleischmann, Fenella. 2015. Understanding the veiling of Muslim women in the Netherlands, Journal for the Scientific Study of Religion, 54(1), 20--37. 
Buğra, Ayşe, and Çağlar Keyder. 2006. "The Turkish welfare regime in transformation." Journal of European Social Policy 16(3):211-28.

Calvo, Ernesto, and Maria Victoria Murillo. 2004. "Who delivers? Partisan clients in the Argentine electoral market." American Journal of Political Science 48(4): 742-757.

Cammett, Melani, Davide Luca, and Ernest Sergenti. 2018. "Unfair play: The politics of Turkey's central government spending under AKP rule.” Working Paper, url (accessed on 05.05.18): https://bit.ly/2GG2VI8

Carvalho, Jean-Paul. (2013). Veiling, Quarterly Journal of Economics, 128 (1), 337-370.

Cattaneo, Matias D., Nicolás Idrobo, and Rocío Titiunik. 2019. A Practical Introduction to Regression Discontinuity Designs: Foundations. Cambridge University Press.

Chen, D.L., 2010. Club goods and group identity: Evidence from Islamic resurgence during the Indonesian financial crisis. Journal of Political Economy, 118(2): 300-354.

Corstange Daniel. 2016. The Price of a Vote in the Middle East: Clientelism and Communal Politics in Lebanon and Yemen. Cambridge: Cambridge University Press.

Çörekçioğlu, Gözde. 2018. "Headscarves and female employment”, European University Institute Working Paper: Florence, url: https://www.dropbox.com/s/pgp1y7vtnfspdwv/jmp_GC.pdf?dl=0 (accessed on 7 June 2018)

de la Cuesta, Brandon, and Kosuke Imai. 2016. "Misunderstandings About the Regression Discontinuity Design in the Study of Close Elections." Annual Review of Political Science 19:375-96.

Davidson, James D., Ralph E. Pyle, and David V. Reyes. 1995. "Persistence and change in the Protestant establishment, 1930-1992." Social Forces 74(1): 157-175. 
Eggers, Andrew C., Anthony Fowler, Jens Hainmueller, Andrew B. Hall, and James M. Snyder. 2015. "On the Validity of the Regression Discontinuity Design for Estimating Electoral Effects: New Evidence from Over 40,000 Close Races." American Journal of Political Science 59(1):259-74.

Festinger, Leon (1957) A Theory of Cognitive Dissonance, Stanford, CA: Stanford University Press.

Fleischmann, Fenella and Phalet, Karen. (2012). Integration and religiosity among the Turkish second generation in Europe: a comparative analysis across four capital cities, Ethnic and Racial Studies, 35(2),320-341.

Francis, Becky, and Merryn Hutchings. 2013 "Parent power? Using money and information to boost children's chances of educational success." Sutton Trust Report url: http://dera.ioe.ac.uk/30277/1/1parentpower-final.pdf (accessed on 7 June 2018).

Gambetta, Diego. 2009. "Signaling”, in P. Hedström and P. Bearman (eds.) The Oxford Handbook of Analytical Sociology, Oxford: Oxford University Press, pp. 168-194

Gangl, Markus. 2010. "Causal Inference in Sociological Research." Annual Review of Sociology 36(1).

Hacettepe University Institute of Population Studies. 2008-2014. "2008-2014 Turkey Demographic and Health Survey." Ankara, Turkey: Hacettepe University Institute of Population Studies, T.R. Ministry of Development and TÜBİTAK.

Hicken, Allen. 2011. "Clientelism." Annual Review of Political Science 14: 289-310.

Iannaccone, L.R., 1992. Sacrifice and stigma: Reducing free-riding in cults, communes, and other collectives. Journal of Political Economy, 100(2): .271-291. 
Kalyvas, Stathis N. 1996. "The rise of Christian democracy in Europe". New York: Cornell University Press.

Kemahlığlu, Ö. and Bayer, R., 2020. Favoring co-partisan controlled areas in central government distributive programs: the role of local party organizations. Public Choice (online advance publication), pp.1-19.

KONDA Research and Consultancy. 2007. Religion, Secularism and the Veil in Daily Life, available from<http:// www.konda.com.tr/html/dosyalar/ghdl\&t_en.pdf $>$.

KONDA Research and Consultancy. 2010. Başını Örtme ve Türban Araştırmas1 [Research on headscarf and türban], available (in Turkish) from<https://konda.com.tr/wpcontent/uploads/2017/03/KONDA 1011 BASINI ORTME VE TURBAN.pdf>

Imbens, Guido, and Karthik Kalyanaraman. 2012. "Optimal Bandwidth Choice for the Regression Discontinuity Estimator." The Review of Economic Studies 79(3):933-59.

Kuran, Timur. 1995. Private truths, public lies: The social consequences of preference falsification. Cambridge, MA: Harvard University Press.

Kuran, Timur. 2018. "Islam and Economic Performance: Historical and Contemporary Links." Journal of Economic Literature 56: XX-XX.

Mardin, Şerif. 2010. "Türkiye'de Din ve Siyaset [Religion and Politics in Turkey].” Istanbul: İletişim.

Merton, Robert K. (1968) Social Theory and Social Structure. New York: Free Press.

Metin, Onur. 2011. "Sosyal Politika Açısından AKP Dönemi: Sosyal Yardım Alanında Yaşananlar [Social policies of the AKP reign: The case of social aids]." Çalışma ve Toplum Dergisi [Work and Society] 1:179-200. 
Meyersson, Erik. 2014. "Islamic Rule and the Empowerment of the Poor and Pious." Econometrica 82(1):229-69.

Morgan, Steven L, and Christopher Winship. 2007. Counterfactuals and Causal Inference. Methods and Principles for Social Research. Cambridge: Cambridge University Press.

Patel, David S. (2012). Concealing to reveal: The informational role of Islamic dress, Rationality \& Society, 24(3), 295-323.

Rodrik, Dani. 2012. Turkish economy after the global financial crisis. Ekonomi-tek 1(1):41-61.

Ruiter, Stijn and Van Tubergen, Frank. 2009. Religious attendance in cross-national perspective: a multilevel analysis of 60 countries. American Journal of Sociology, 115, 863-895.

Somer, Murat. 2017. "Conquering versus democratizing the state: political Islamists and fourth wave democratization in Turkey and Tunisia." Democratization 24(6): 1025-1043.

Spence, Michael 1974. Market Signaling. Cambridge, Mass.: Harvard University Press.

Stokes, Susan C., Thad Dunning, Marcelo Nazareno, Valeria Brusco 2013. Brokers, Voters and Clientelism. The puzzle of Distributive Politics. Cambridge: Cambridge University Press.

Thistlethwaite, Donald L, and Donald T Campbell. 1960. "Regression-discontinuity analysis: An alternative to the ex post facto experiment." Journal of Educational Psychology 51(6):309.

Titiunik, Rocio. 2020. "Natural experiments". arXiv preprint arXiv:2002.00202.

Umit, Result (2018) Istanbul puts the money where AKP voters are, blog post at Medium. url: https://medium.com/@ resulumit/istanbul-puts-the-money-where-the-akp-voters-are4f60727c88e1 (accessed on 18.12.2018)

Voas, D. (2007). Surveys of behaviour, beliefs and affiliation. In Handbook of the Sociology of Religion, eds. J Beckford and NJ Demerath, pp. 128-50. London: Sage. 
Yavuz, M Hakan. 2000. "Cleansing Islam from the Public Sphere." Journal of International Affairs 54(1):21.

Yoltar, Ç., 2009. When the poor need health care: Ethnography of state and citizenship in Turkey. Middle Eastern Studies, 45(5), pp.769-782.

Zahavi Amotz and Avishag Zahavi 1998. The Handicap Principle. Oxford: Oxford University Press. 
Appendix to "Politics behind the veil"

For online publication only 


\section{Contents}

Appendix A: A formal model of political signalling and patronage 59

Appendix B: Validity checks and robustness of Regression Discontinuity Design results ....................65

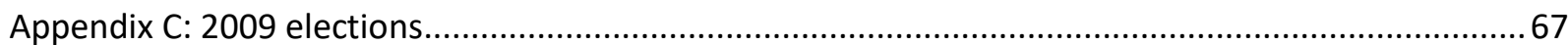

Appendix D: items used in measuring gender norms and values................................................68 


\section{Appendix A: A formal model of political signalling and patronage}

We will assume religiosity has a standard uniform distribution $r \sim U[0,1]$. The AKP has a budget $\mathrm{K}$ for patronage, where $\mathrm{K} / \mathrm{N}=b$, that is if AKP's budget $\mathrm{K}$ is equally distributed across the electorate each actor gets a premium of $b$. For an actor $j$, the utility of voting for the AKP is $\mathrm{U}(\mathrm{AKP})=a+c r_{j}+b_{j}+e . a$ and $c>0$ are fixed model parameters. $r_{\mathrm{j}}$ is $j$ 's level or religiosity and $b_{j}$ is the client premium $j$ gets from the AKP. So, the utility of voting AKP increases linearly in religiosity and in the client's premium from the party. $e$ is a random utility term. We will normalise the utility from voting for an alternative party or not voting at all as $\mathrm{U}(-\mathrm{AKP})=0+e$. We further assume that $e$ is i.i.d. with an extreme value distribution. This implies that an actor votes for the AKP with probability $=\frac{1}{1+e^{-a-c r_{j}-b_{j}}}$.

Straightforward calculation shows that the marginal effect of $b$ (a client's benefit from the AKP) on the actor's probability for voting AKP is $p(1-p)$. That is, $b$ will have a smaller effect for those who have an a priori low likelihood of voting for the AKP (e.g. seculars) than moderates (i.e. those who have around half a chance of voting for the party). Similarly, those who are very religious are very likely vote for the AKP anyways, so a client's premium $b$ will have a smaller effect on them, too. Ideally, the AKP would like to allocate benefits to those with a $p$ around 0.5. However, there is no way of identifying those voters in the model, since $r$ is unobservable by the AKP.

AKP can distribute the patronage budget to all electorate equally, in which case each actor gets $b$. In this case, the vote share of the AKP is given by the integral below:

$$
\int_{0}^{1} \frac{1}{1+e^{-a-c r-b}} f(r) d r
$$

where $f(r)$ is the probability density function of religiosity where $r \sim U[0,1]$ so that $f(r)=1$. The above integral can be solved by integration by parts:

$$
\int \frac{1}{1+e^{-a-c r-b}} f(r) d r=\frac{\ln \left(e^{a+c r+b}+1\right)}{c}+C
$$

The overall vote share of the AKP when patronage is distributed equally can then be calculated as:

$$
\frac{1}{c}\left[\ln \left(e^{a+c+b}+1\right)-\ln \left(e^{a+b}+1\right)\right]
$$

Could AKP do any better than distributing patronage equally across the electorate? Let's assume there is an observable and costly religious behaviour, $v$, and displaying $v$ gives $j$ a utility of $-i+$ $r_{j}$. So, $i$ is the cost of displaying that religious behaviour such that only those with $r>i$ would display that behaviour. Because $v$ is observable, and is correlated with unobservable religiosity $r$ and hence with the likelihood of voting for the AKP, the AKP can choose to distribute $\mathrm{K}$ (the patronage budget) over only those who display $v .{ }^{14}$ However, distributing resources to those who

${ }^{14} \mathrm{AKP}$ could also decide to distribute K over those who do not display $v$, but we will come to that later. 
display $v$ would also make $v$ more attractive. Therefore some actors who normally do not do $v$ will start doing $v$. In fact, if AKP decides to reward $v$, everybody whose religiosity is above a certain threshold $\mathrm{r}^{*}<i$ would do $v$. Note, that because AKP is distributing resources to only those who do $v$, per capita benefit from AKP increases from $b$ to $b /\left(1-r^{*}\right)$ for those who do $v$ (that is $\mathrm{K}$ is not distributed across all electorate, but across a subset of the electorate who display $v$ ). In this case, those who do not display $v$ will receive zero benefits from the AKP. Note also that for sufficiently high $b$ (e.g. $b>i$ ), $v$ becomes universal, in which case distributing premiums across all electorate and across those who display $v$ will result in the same outcome for the AKP. The equilibrium value of $r^{*}$ when the AKP rewards $v$ can be found as below:

$$
r^{*}=\frac{1-i \pm \sqrt{(1-i)^{2}+4(i+b)}}{2} \text { with } 0 \leq r^{*} \leq 1 .
$$

That is, if AKP rewards those who do $v$, everybody whose religiosity is above $r^{*}$ would do $v$, otherwise not do $v$. In that case, $b_{\mathrm{j}}=0$ if $r<r^{*}$ and $b_{\mathrm{j}}=b /\left(1-r^{*}\right)$ if $r>r^{*}$. But would AKP prefer to do this? The vote share of the AKP if it rewards $v$ will be:

$$
\int_{0}^{r^{*}} \frac{1}{1+e^{-a-c r}} f(r) d r+\int_{r^{*}}^{1} \frac{1}{1+e^{-a-c r-\frac{b}{1-r^{*}}}} f(r) d r
$$

This integral evaluates to:

$$
\frac{1}{c}\left[\ln \left(e^{a+c r^{*}}+1\right)-\ln \left(e^{a+b}+1\right)+\ln \left(e^{a+c+\frac{b}{1-r^{*}}}+1\right)-\ln \left(e^{a+c r^{*}+\frac{b}{1-r^{*}}}+1\right)\right]
$$

Compared with the case where AKP distributes K over all electorate, distributing K over only those who display $v$ gives a higher payoff for AKP when (2) is larger than (1). Whether (2) is larger than (1) depends on how costly $v$ is relative to the size of AKP's patronage budget (and obviously to other model parameters $a$ and $c$ ). If $\mathrm{K}$ is too large, relative to the cost of $v$, than rewarding $v$ makes $v$ universal, so $(2)=(1)$, and AKP could do either. If the cost of $v$ is too high, only very few actors would display $v$ and unless $\mathrm{K}$ is too high. In that case, rewarding a handful of electorate who display $v$ would not be very beneficial for the AKP. In fact, if $v$ is too costly, rewarding those who do not display $v$ could be better for the AKP than rewarding all or rewarding those who do $v$. When the cost of $v$ is not too high so that a substantial proportion displays $v$ and the cost of $v$ is not too low so that rewarding it does not make it universal, rewarding $v$ will be more beneficial for AKP than distributing the patronage budget to the entire electorate. This mechanism is demonstrated below.

\section{A demonstration}

Figure K1 below shows how the model works. In Panel A, the AKP does not provide any premium to the electorate. The $\mathrm{x}$-axis is religiosity. The black curve is the probability for voting for AKP, the maroon line is the utility of displaying the religious behaviour $v$. Only those with $r$ $>0.55$ (hence $45 \%$ ) do $v$. In this case, the vote share of the AKP is $43.25 \%$. In panel B, the AKP provides the client's premium $b$ to all of the electorate. Because everybody has access to $\mathrm{b}$, the maroon line do not move. However, the probability of voting for AKP shifts up, and more so for 
those who have a baseline voting probability of 0.5 . In this case, the vote share of the AKP increases to $44.59 \%$. In panel C, the AKP distributes the premium $b$ to only those who display $v$. Because $v$ is rewarded by the AKP, the maroon line shifts inwards (hence the blue line). Now those with $r>r^{*}=0.387$ display $v$ (hence 61\%). AKP rewards only those who do $v$, so premium $b$ is shared by $61 \%$ only, hence per capita premium increases. Now the red curve shows the probability for voting for the AKP. Compared with the baseline case (the black curve in panel A) those who do not do $v$ did not change their probability of voting for the AKP. Those who do $v$, however, increase their probability of voting AKP and more so if the baseline probability is close to 0.5 . In Panel C, the vote share of the AKP is $44.94 \%$, the highest payoff to the AKP.

Figure K2 shows a case in which $\mathrm{v}$ is too costly $(i=0.90)$ so that only $10 \%$ initially do $v$. In this case rewarding $v$ makes $v$ more mainstream: the prevalence of $v$ increases to about $37 \%$. However, the vote share of the AKP is lower if the AKP rewards only those who display $v$ (44.5\%) than if AKP distributes the rewards to the entire electorate (44.6\%). This happens because firstly too few people display the costly act, hence rewarding a small audience increases the AKP votes only marginally. Secondly, those who display $v$ when it is costly are those who already have a high probability of voting for the AKP. Rewarding them increases this already high probability only marginally.

Figure K3 shows the AKP vote share for all possible values of $i$ keeping all other parameters constant. The maroon line displays AKP's vote share when AKP distributes rewards to all electorate and the blue line is when the AKP distributes rewards to those who only do $v$. The $\mathrm{X}-$ axis is how costly $v$ is $(i)$. The figure shows that if $\mathrm{v}$ is not very costly $(i<0.1)$ the two curves overlap. But when $i$ is highly costly $(i>\sim 0.82)$ rewarding only $v$ makes AKP worse off than distributing resources to the entire electorate.

Obviously, depending on other game parameters the range of $i$ which makes AKP better of rewarding $v$ varies. For instance in $\mathrm{K} 4 \mathrm{c}=6$, so the association between religiosity and likelihood of voting AKP is weaker than that in $\mathrm{K} 3$. In that case, rewarding $v$ is always better for the AKP than rewarding all for all $i>0.1$. When $i<0.1$, rewarding all and rewarding $v$ give AKP the same payoff. 
Figure K1
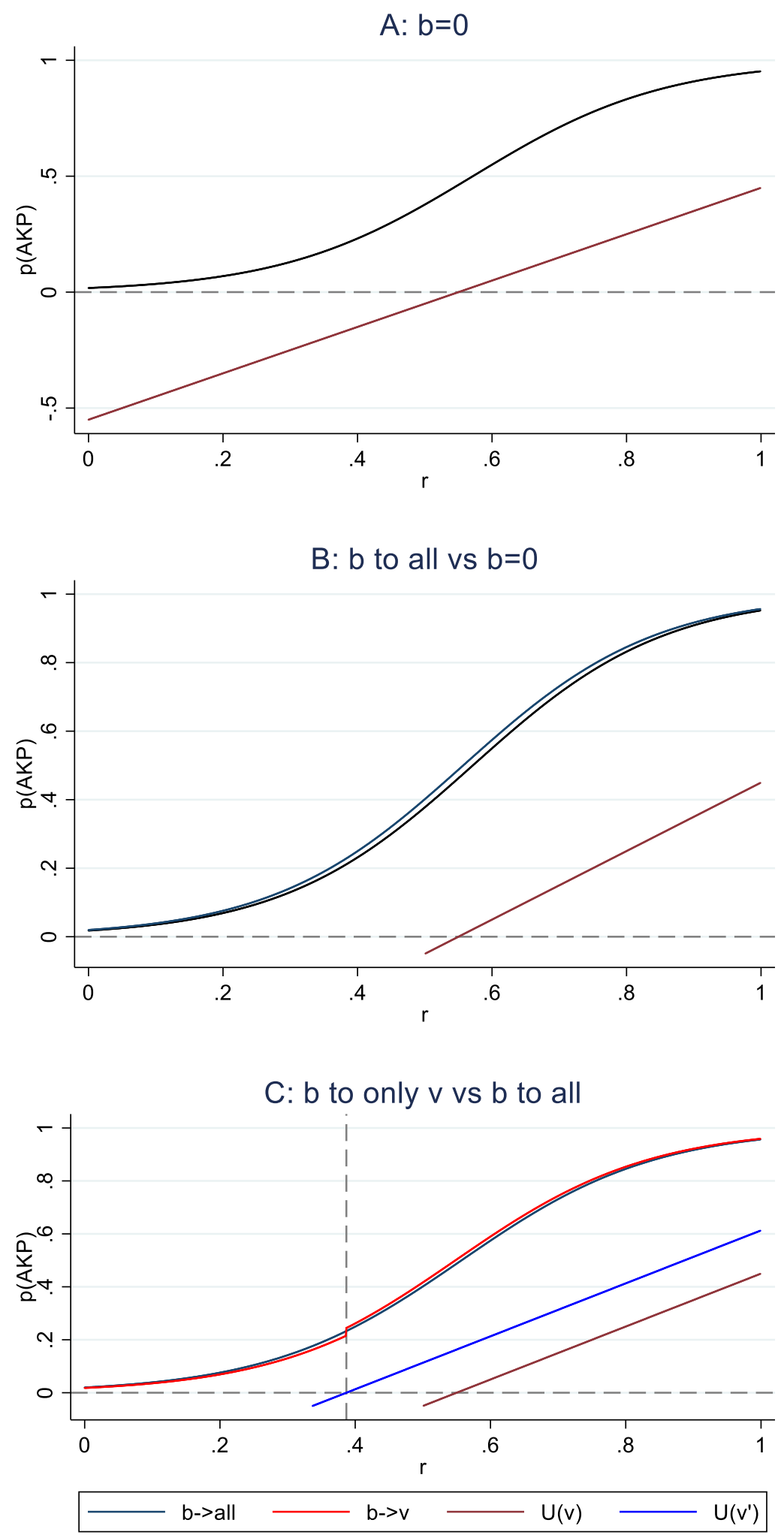

Note: $a=-4, b=.1, c=7,-i=-.55$ 
Figure $\mathrm{K} 2: \mathrm{b}$ to $\mathrm{v} v \mathrm{vs} \mathrm{b}$ to all when $\mathrm{v}$ is very costly

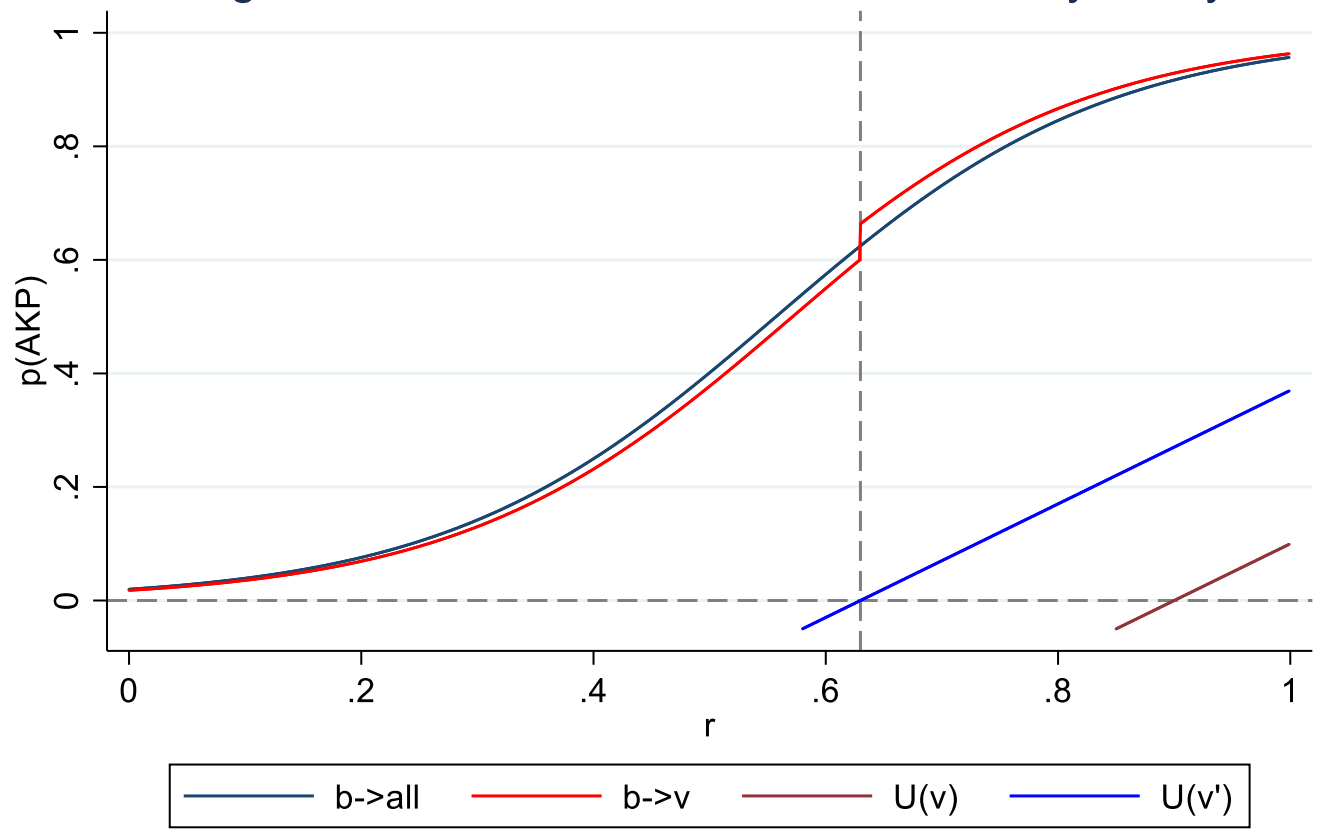

Note: $a=-4, b=.1, c=7,-i=-.9$

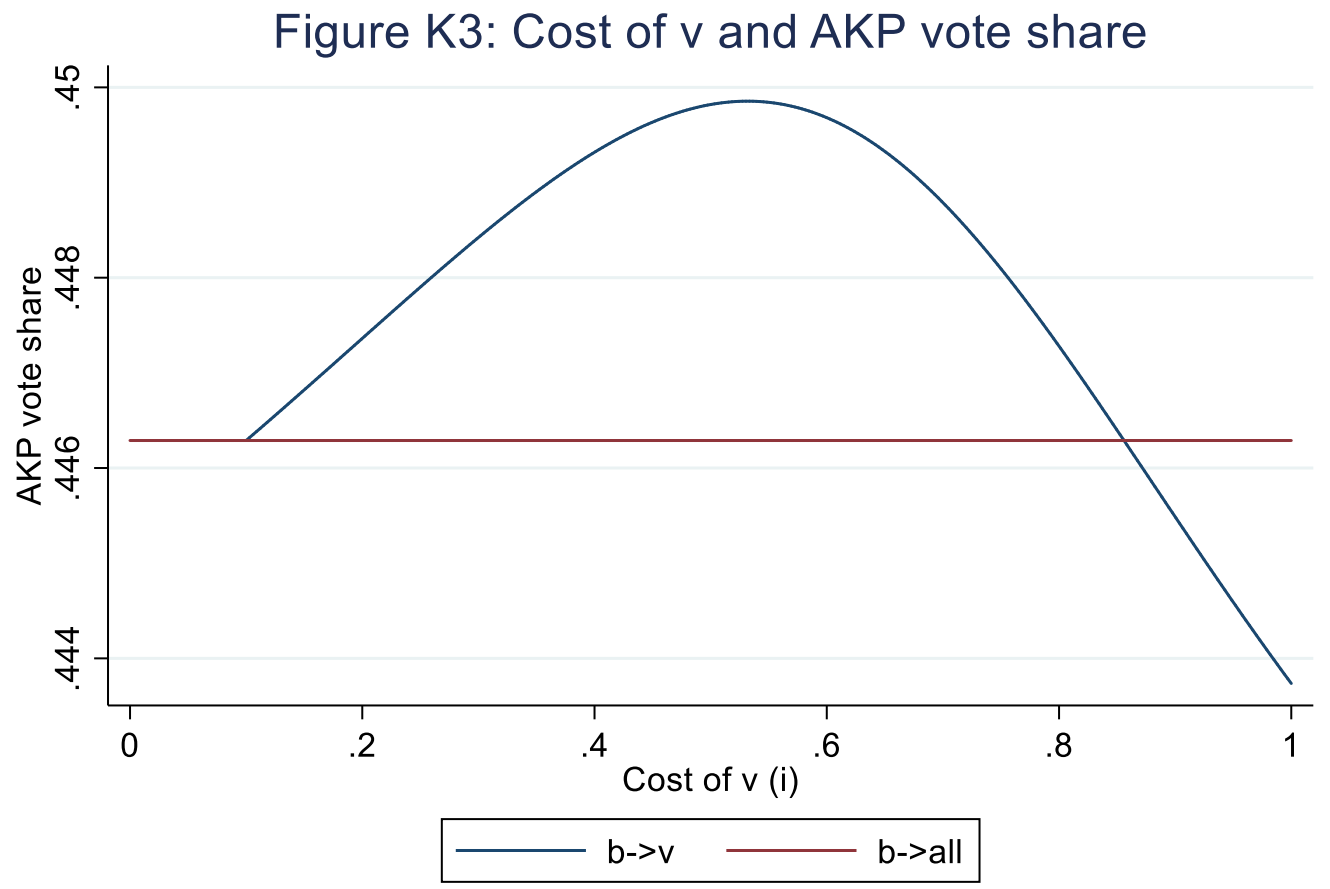

Note: $a=-4, b=.1, c=7$ 
Figure K4: Cost of $v$ and AKP vote share with $c=6$

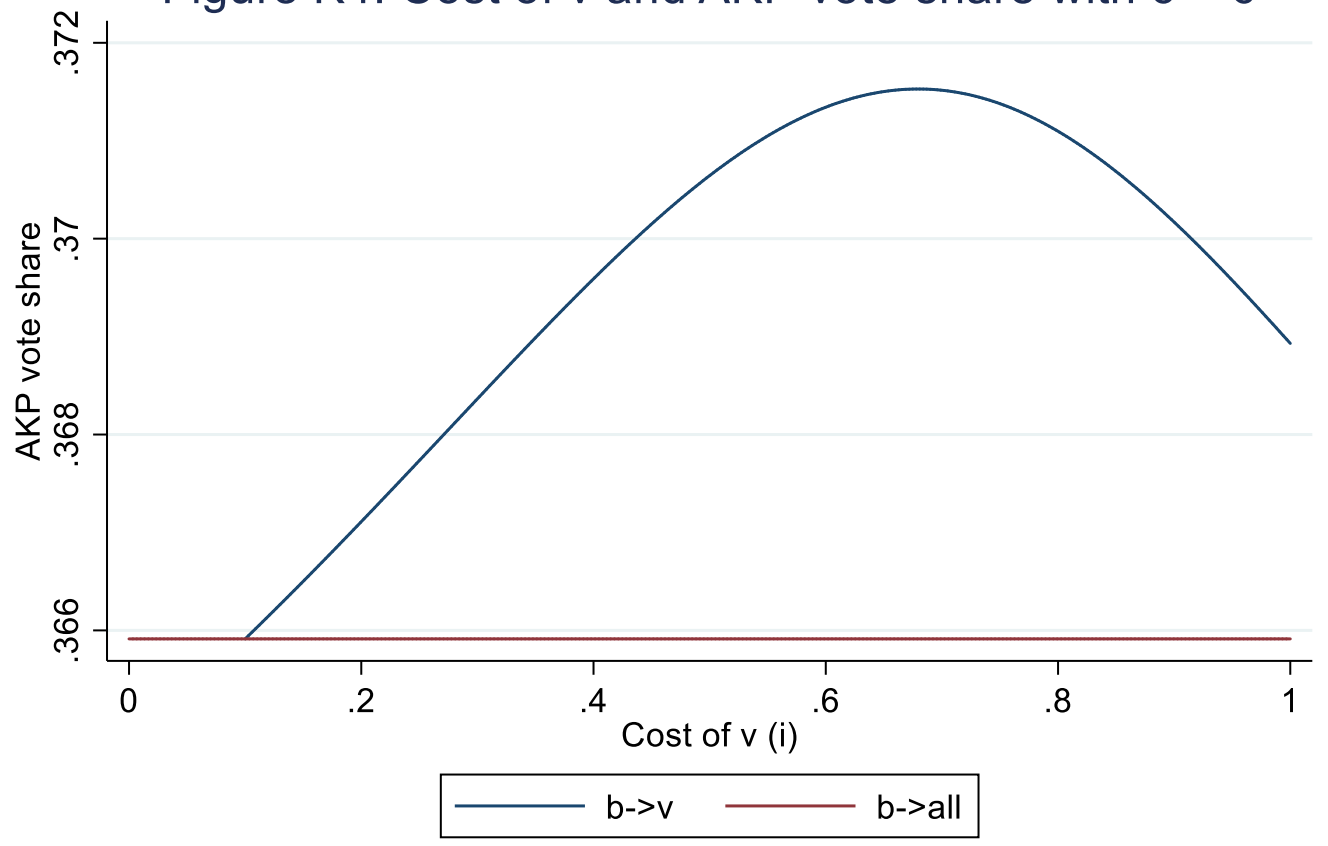

Note: $a=-4, b=.1, c=6$ 


\section{Appendix B: Validity checks and robustness of Regression Discontinuity Design results}

This section provides a number of validity tests of a Regression Discontinuity Design in our context. Firstly, Figure B1 shows visually the McCrary density test. While there seems to be some jump at the threshold, the discontinuity of the running variable is insignificant (discontinuity estimate $=.491$, S.E. $=$ .646). Figure B2 shows the vote share of the Virtue Party (the predecessor of the AK Parti) in a province versus the AK Parti win/lose margin in 2004. If the support for political Islam before the 2004 elections (measured by the vote share of Virtue) were significantly different around the winning threshold in 2004, that would have indicated sorting and invalidated the RDD. We do not find evidence for this in the data (RD effect of AK Parti in 2004 on Virtue share in $1999=.03$, S.E. $=.056$ ).

Table B1 shows the results of a number of additional placebo tests that check if there is significant difference around the 2004 province-level winning/loosing threshold with respect to a number of variables that should not be affected by treatment. These variables are age, ethnicity (Turkish vs. any other ethnicity and Kurdish versus any other ethnicity), geographical region (West vs. any other region, Central vs. any other region, East vs. any other region), survey year (2013 versus 2008). None of the placebo tests are statistically significant.

Table B1. Placebo tests: Regression Discontinuity effects of Islamic Governance on some pre-treatment variables.

\begin{tabular}{lllll}
\hline & RD effect & Robust S.E. & P-value & KI optimal b.width \\
\hline Age & -0.029 & 0.775 & 0.970 & 0.166 \\
Ethnicity & & & & \\
$\quad$ Turkish (vs rest) & -0.171 & 0.165 & 0.301 & 0.042 \\
$\quad$ Kurdish (vs rest) & 0.163 & 0.156 & 0.294 & 0.041 \\
Region & & & & \\
$\quad$ West (vs rest) & -0.021 & 0.147 & 0.886 & 0.046 \\
$\quad$ Central (vs rest) & -0.093 & 0.144 & 0.519 & 0.097 \\
$\quad$ East (vs rest) & 0.528 & 0.358 & 0.140 & 0.035 \\
Survey year (2013 vs 2008) & -0.067 & 0.059 & 0.261 & 0.187 \\
\hline
\end{tabular}


Figure B1: McCrary density test of the running variable around the threshold.

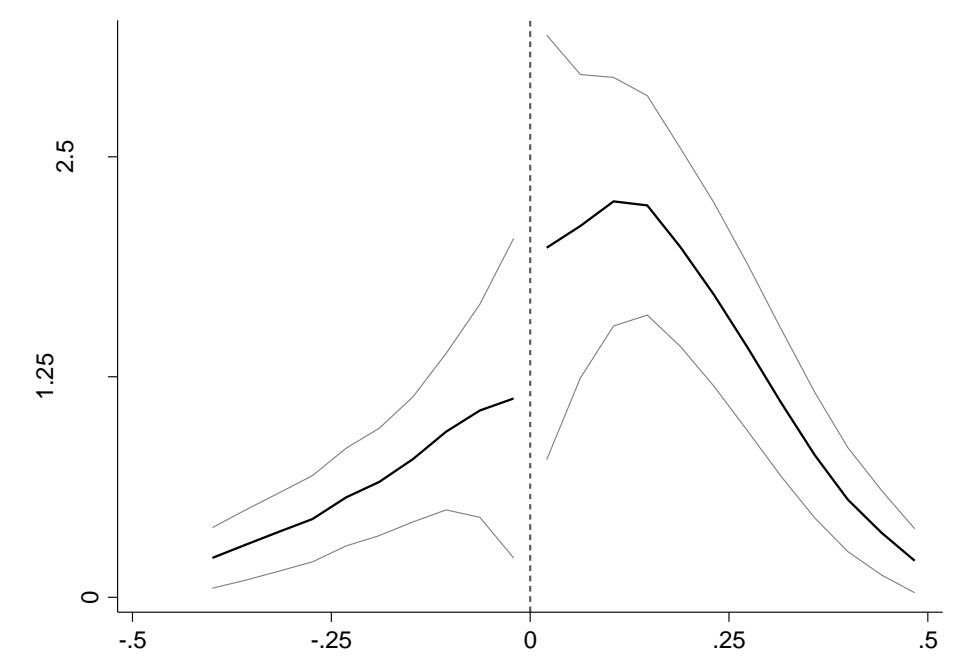

Figure B2: Vote share of the Virtue Party (predecessor of the AK Parti) in 1999 versus the AK Parti winning/losing margin at the province-center.

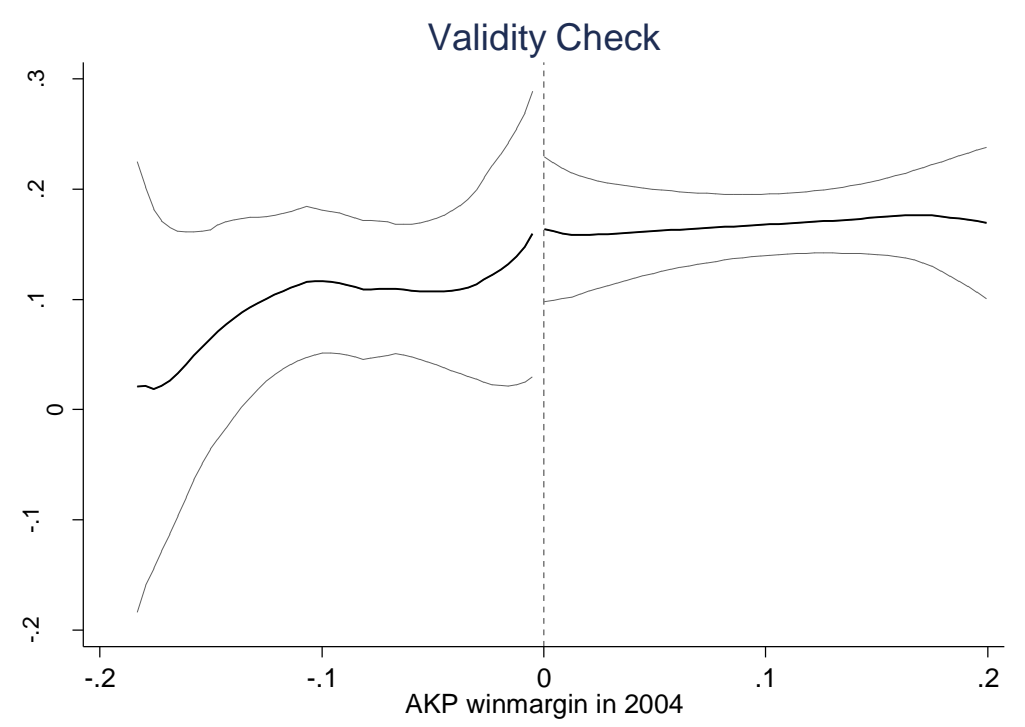


Table B2: Regression Discontinuity effect estimate for outcome variable Pr(veiling) in 2013, its cluster robust standard error, associated p-value, and a p-value corrected for multiple testing for a number of arbitrary cutoffs and the real 0 cutoff.

\begin{tabular}{|c|c|c|c|c|}
\hline $\begin{array}{c}\text { Placebo (real) } \\
\text { cutoff value }\end{array}$ & $\begin{array}{c}\text { RDD } \beta \\
\text { [marginal } \\
\text { effect] }\end{array}$ & $\begin{array}{c}\text { Cluster robust } \\
\text { S.E. }\end{array}$ & P-value & $\begin{array}{c}\text { Bonferroni } \\
\text { Adjusted } \mathrm{p}- \\
\text { value }\end{array}$ \\
\hline-0.09 & .071 & .127 & 0.573 & 1 \\
-0.08 & -.164 & .118 & 0.165 & 1 \\
-0.07 & -.328 & .146 & 0.025 & 0.475 \\
-0.06 & -.014 & .127 & 0.911 & 1 \\
-0.05 & -.044 & .130 & 0.738 & 1 \\
-0.04 & .339 & .207 & 0.102 & 1 \\
-0.03 & -.067 & .145 & 0.645 & 1 \\
-0.02 & -.047 & .131 & 0.723 & 1 \\
-0.01 & .0503 & .112 & 0.652 & 1 \\
$\mathbf{( 0 . 0 0 )}$ & .245 & .073 & $\mathbf{0 . 0 0 1}$ & $\mathbf{0 . 0 1 9}$ \\
0.01 & .075 & .105 & 0.473 & 1 \\
0.02 & -.207 & .122 & 0.091 & 1 \\
0.03 & -.092 & .097 & 0.343 & 1 \\
0.04 & -.154 & .099 & 0.121 & 1 \\
0.05 & -.147 & .099 & 0.138 & 1 \\
0.06 & -.151 & .105 & 0.152 & 1 \\
0.07 & -.127 & .114 & 0.267 & 1 \\
0.08 & .061 & .082 & 0.454 & 1 \\
0.09 & .308 & .178 & 0.084 & 1 \\
\hline
\end{tabular}

Table B2 above presents RD effect estimates for various placebo cutoff values including the true cutoff value of zero for the outcome variable of $\operatorname{Pr}($ veiling) in 2013. None of the estimates obtained with placebo cutoffs is statistically significant at the 0.01 level and none remains statistically significant after multiple test corrections, except the estimate obtained using the real cutoff value of zero.

The RD effect on veiling in 2013 remain virtually unchanged after controlling for veiling prevalence in the province in 2003 and 2008 ( $\beta$ [marginal effect] $=0.20, \mathrm{P}=0.004)$. We further checked whether the support for political Islam before the 2004 elections affects the effect of the 2004 elections. After controlling for the vote share of the Virtue Party in 1999 our RD estimates remain virtually identical ( $\beta$ [marginal effect] in $2013=0.23, \mathrm{P}=0.008 ; \beta$ [marginal effect] in $2008=0.07, \mathrm{P}=0.314$ ). Neither the vote share of the Virtue in 1999 nor a binary indicator of whether the province centre is ruled by the Virtue after 1999 interacts significantly with the discontinuity in 2004.

\section{Appendix C: 2009 elections}

There is a further substantive validation we can pursue. After the 2004 elections, which are our main focus, there was another round of local elections in 2009. This gives us an opportunity to conduct a validation test by checking what happens in provinces gained by the AK Parti in 2004, but went to another party in 2009. In particular, we expect that in provinces in which the AK Parti lost the elections in 2009, the effect predicted in Hypothesis 1 should be lower. In other words, once the cause is off, the effect should wane. We test this expectation by adding to equation (1) an interaction between the treatment indicator and a dummy indicator of whether the province swung away from the AK Parti in 2009. As we expected, this interaction is negative and statistically significant $(\beta=-0.16, P=0.022)$. The RD effect of the AK Parti in 2004 on veiling probability in 2013 is about 0.34 in provinces that did not 
swing away from the AK Parti, while in provinces lost by the AK Parti in 2009 the effect on veiling does not disappear, but is significantly smaller.

We do not find any significant RD effect of 2009 elections on veiling in 2013 (RD marginal effect $=-.03$, cluster-robust $\mathrm{SE}=.08, \mathrm{P}=0.753$ ). We have to note, however, that in 2009 in 72 percent of provinces the winner (AK Parti vs. another party) did not change. Hence, the majority of the provinces which received the "treatment" in 2009 has already received it in 2004, leaving little statistical power to detect treatment effects for the previously untreated. Also, the 2009 elections came at a special time, right after the great recession. The recession disturbed the social and political dynamics and a portion of the electorate chose to punish the governing AK Parti. The AK Parti lost more of its mayoralties than it won new mayoralties in 2009. The AK parti won both in 2004 and 2009 in 50\% of all provinces; it lost 18 provinces in 2009 in which it won in 2004, and gained 5 provinces which it had lost in 2004. Overall, compared with 2004, the AK Parti vote share decreased by three points to 39\% in 2009.

\section{Appendix D: items used in measuring gender norms and values}

The TDHS08 and TDHS13 items recode if a respondent agrees with the following. (1) "The important decisions in the family should be made only by men", (2) "men should also do the housework like cooking, washing, ironing, and cleaning", (3) "it is better to educate a son than a daughter", (4) "women with children should not work outside the home", (5) "women should be more involved in politics", and (6) "women should be virgin when they get married". The TDHS03 items comprise item 1, 3, and "Men are usually wiser than women" and "If a woman disagrees with her husband, she should not argue with him, and keep quiet." We standardize the gender norms and values variable and household wealth. 